\title{
Architecture and Violence: \\ Between Representation and Exchange
}

By

Jenan Ghazal

A thesis submitted to the Faculty of Graduate and Postdoctoral Affairs in partial fulfillment of the requirements for the degree of

Master of Architecture

In

Master of Architecture Studies

Carleton University

Ottawa, Ontario

(C) 2016, Jenan Ghazal 


\section{Abstract}

This thesis focuses on spaces that have experienced brutal and radical transformations, in cities that have endured war, asking what architecture becomes when it collides with violence. While it dramatically alters architecture, destruction does not seem to belong to any architectural discourse. Hence, architecture as destruction becomes merely a product of violence. However, this research discusses destruction differently, it argues that when destruction impacts architecture, it should not be seen as a final act, rather architecture acquires new meanings. Analyzing the relationship between architecture and violence starts with investigating the human component in an attempt to explore a triangle between humans, violence, and architecture. How do perpetrators of violence carry out destruction without hesitation? Do they give up thinking and blindly follow orders? Is architecture often targeted because of what it represents? Does architecture contribute to empowering violence or resisting it?

The research's intention resides not in presenting answers, but in reading and exploring some crucial ideas around the human experience of violence and its relation to architecture. It argues that architecture can transform violence as much as violence transforms architecture.

Key words: Architecture, City, Citizens, Destruction, Representation, Reconstruction, Violence, War. 


\section{Acknowledgements}

I Thank God, for his uncountable blessings, my journey in Canada is one of them...

My first two academic years in Carleton University are one of the hardest, most challenging, yet incredible years of my life.

Somewhere along the way, I could have lost direction if not for some exceptional people who guided me throughout hard times, and still do today.

First of all, I owe my deepest gratitude to my advisor Professor Stephen Fai, chair of the $\mathrm{PhD}$ program of the Azrieli School of architecture and Urbanism. He believed in my potential to write and research in an academic frame even when I didn't. I am extremely thankful and indebted to him for sharing expertise, for his sincere and valuable guidance and encouragement extended to me from the first day I met him.

The door to Prof. Jerzy Elzanowski's office was always open whenever I ran into a trouble spot or had a question about my research or writing. As my co-advisor, he consistently allowed this research to be my own work, but steered me in the right direction whenever he thought I needed it.

I am also grateful to Professor Federica Goffi, Associate Director of the Graduate programs. My first graduate class was a great learning experience, I thank her for the continuing support and encouragement. I would like also to thank the rest of the committee members: Professor Michael Windover as the external from the Art History department, and Professor Ivan Cazabon as the chair from the architecture department. The engaged conversation we had is an exceptional experience to me.

Though only my name appears on the cover of this dissertation, many special people have contributed in many ways to its completion:

My friends have helped me stay sane through these difficult years. Their support and care helped me overcome setbacks and stay focused on my graduate study. I greatly value their friendship and I deeply appreciate their belief in me.

Most importantly, none of this would have been possible without the love and patience of my immediate family to whom this thesis is dedicated to. They have been a constant source of love, concern, support and strength all my life. The reason I aspire for greatness is my father. The reason I become who I am is my mother. The reason I cherish what I do is my brothers and sisters, I hope when they look at me, they find someone worth looking up to.

My extended family has also aided and encouraged me throughout this endeavor. And finally, the reason I continue to do all this, through hard times, is my husband. This accomplishment would not have been possible without you. Thank you.

Jenan Ghazal

May 2, 2016

Ottawa, Canada 


\section{Table of Contents}

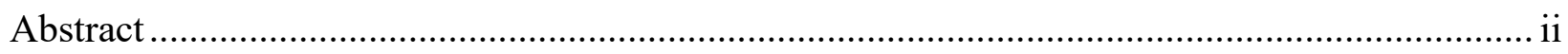

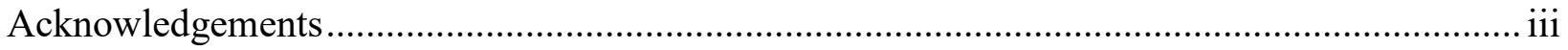

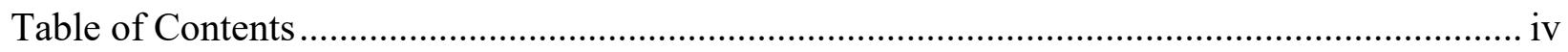

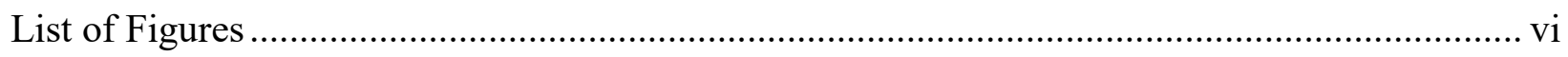

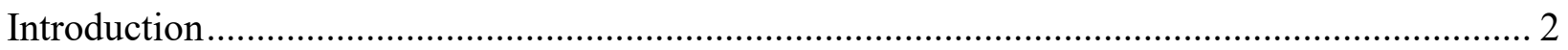

Crossroads of Architecture and Violence: A Personal Tale …………….................................. 2

First space. Constructing Destruction: The Perpetrators of Violence............................................. 11

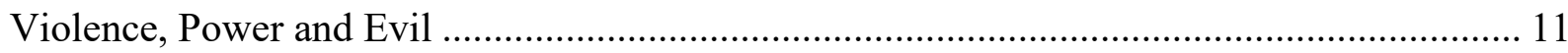

Accounts of Destroyers and the Destruction of Cities............................................................ 14

Obedience to Authority, and Compliance to Violence …………………….......................... 18

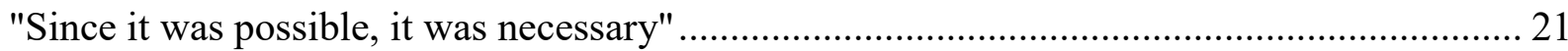

Second space. Architecture in the City: The Target of Destruction ............................................... 25

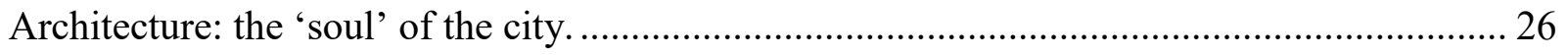

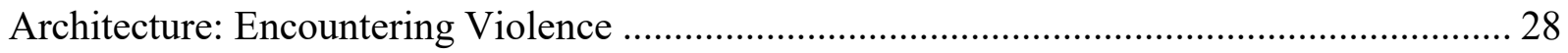

Architecture: The Representation of Culture/Target/Physical Reminder ................................. 30

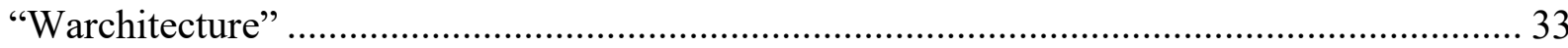

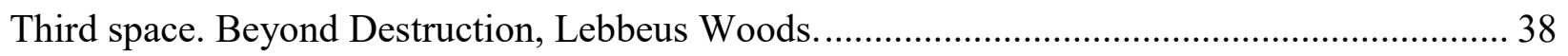

Architecture: Knowledge/Matter, Order/Chaos ................................................................... 39 
Woods' interpretation of War and Architecture 40

Destruction/ Reconstruction: New Concepts of Engagement.................................................. 43

Fourth space. Architecture and violence in the City: A personal tale. ...................................... 47

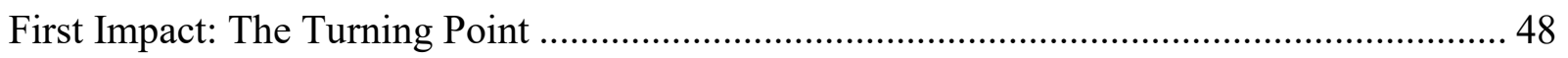

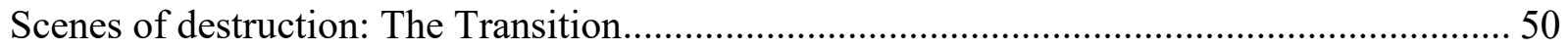

Conclusion. Violence and Architecture: Towards new beginnings ............................................. 60

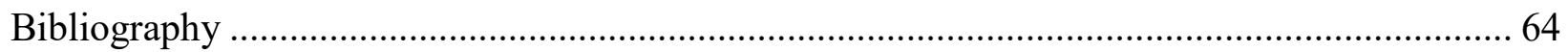

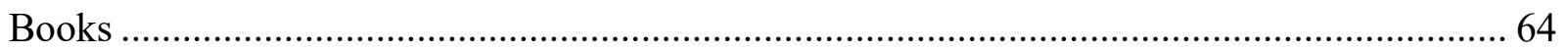

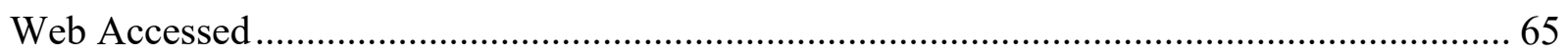

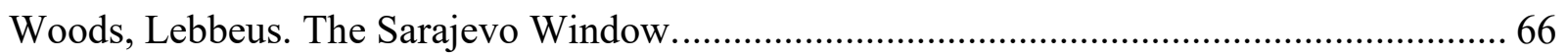




\section{List of Figures}

Figure 1: A kiss for the whole world: Tammam Azzam's version of Klimt's "The Kiss." ............ 1

Figure 2: Jamal Saidi/Reuters. "The damage outside al-Salam mosque ...................................... 4

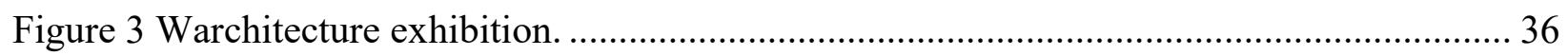

Figure 4: Destruction of Gazi Husrev-beg Mosque .................................................................. 37

Figure 5: Lebbeus Woods. The burning Electrical Management Building ................................. 42

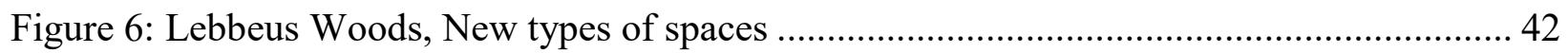

Figure 7: Lebbeus Woods, Nine Reconstructed Boxes ........................................................... 45

Figure 8 and 9: Lebbeus Woods. (Above and below) A typical residential block ........................ 46

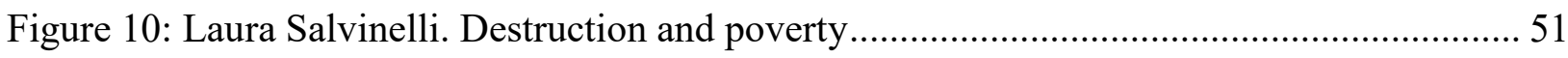

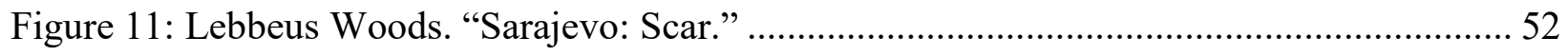

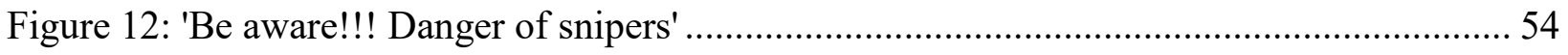

Figure 13: Bettmann/Corbis. Londoners shelter in a tube station ............................................. 57

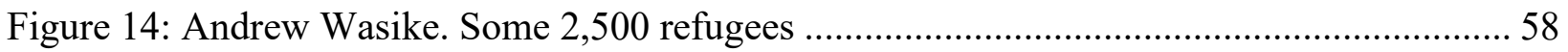




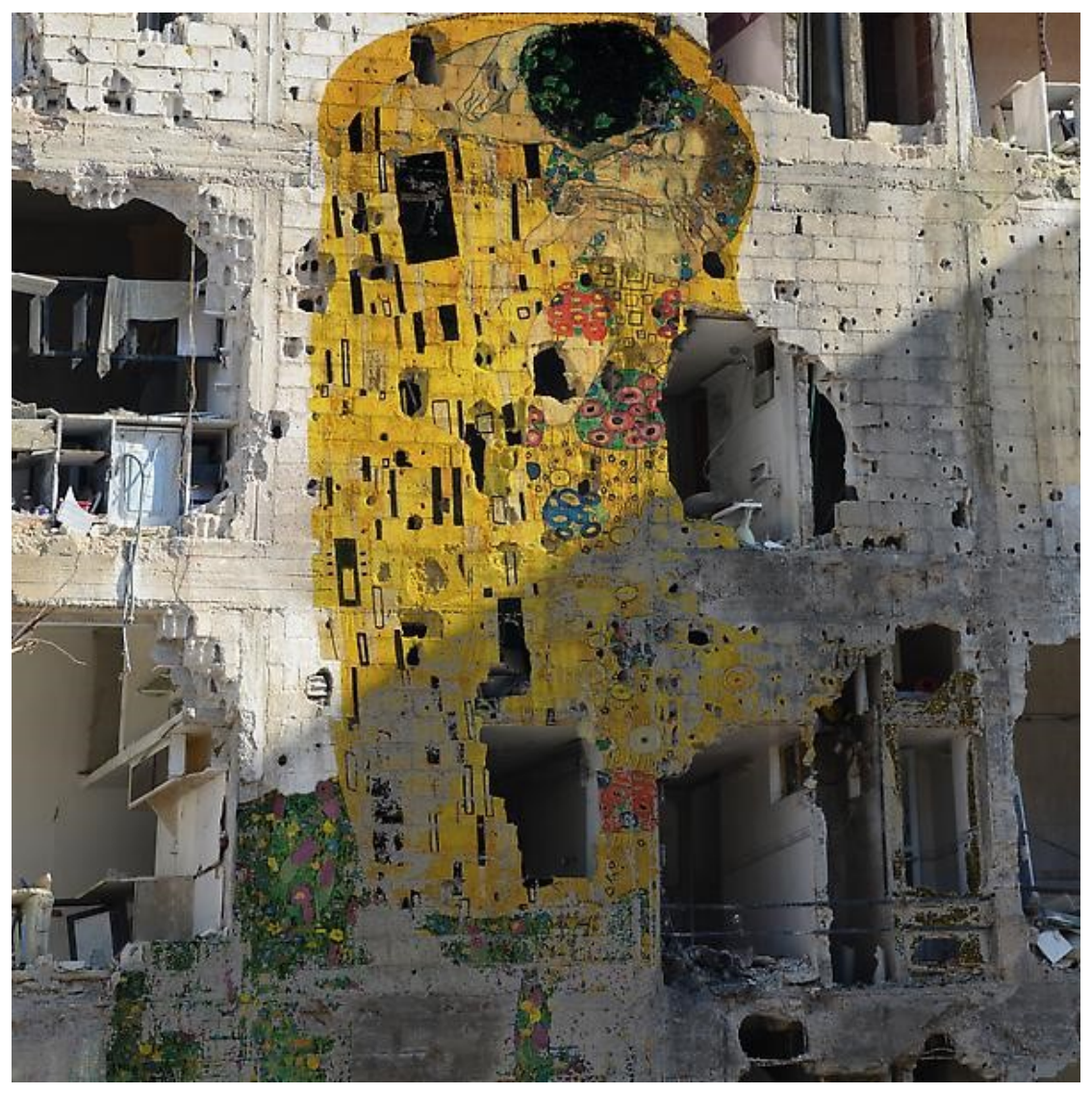

Figure 1: A kiss for the whole world: Tammam Azzam's version of Klimt's "The Kiss." Source: The Guardian.

http://www.theguardian.com/artanddesign/jonathanjonesblog/2013/feb/04/syria-klimtkiss-tammam-azzam 


\section{Introduction}

In 1908 and 1909, Austrian artist Gustav Klimt painted his most famous work, "The Kiss," representative of what is now known as the golden period of his career. In 2012, Syrian artist Tammam Azzam created a large photo montage of Klimt's gold and yellow painting on the grey and black concrete façade of a destroyed apartment building in Damascus. It was part of an exhibition entitled "I, the Syrian." This turned Azzam into an international artist, far beyond the Middle East. " "Freedom Graffiti" includes bullet holes, crumbling walls, and a nearly falling structure as the background for Klimt's two lovers kissing peacefully. The image seems to convey a theatrical play, staging art and architecture along with violence in one coherent body. But does this re-appropriation of Klimt reveal violence as a possibility for cultural production, and culture as a resource for framing and resisting violence? Can violence be both exhibited through, and exert a force on, architecture?

\section{Crossroads of Architecture and Violence: A Personal Tale}

It was the summer of 2013. Almost one year after the outbreak of the Syrian war, Tripoli, a city in northern Lebanon near the Syrian border, was dragged into chaotic destruction. After the end of the Lebanese civil war that lasted from 1975 until 1990, two neighborhoods in Tripoli had remained highly tense, and the war in Syria triggered another war between part of the city's Sunni Muslims located in the city, and the Alawite communities located in Tripoli's suburban Jabal Mohsen district. During a Friday prayer on 23 August 2013, twin car bombings

\footnotetext{
${ }^{1}$ Jonathan Jones, "Tammam Azzam's Kiss: An Unromantic Commentary on the Syrian Conflict," The Guardian, 4 February 2013, http://www.theguardian.com/artanddesign/jonathanjonesblog/2013/feb/04/syria-klimt-kiss-tammamazzam.
} 
simultaneously targeted two of the most prominent mosques in the city; the attack was the deadliest since the end of Lebanon's Civil War. ${ }^{2}$

Indeed, the amount of damage was significant, and on the Sunday following the shock, with the help and resources of the local community and NGOs, citizens immediately grouped themselves into teams to assess the damage and begin reconstruction. I joined a team led by a mother, her teenage daughters and their friends. The first apartment on our list belonged to a senior citizen. Despite all the destruction around him, he was elegantly dressed in a suit, though he was not the only one; it seemed as if citizens needed a sense of order amidst all the chaos surrounding them. First, the team started collecting large pieces of shattered glass, and then smaller ones, until our area, to an extent, could be considered "safe." The team leader constantly reminded us to discard everything destroyed in a big black box, which would later be transported to a dumping facility. A strong will, and perhaps an even stronger need, could be sensed among everyone present in that area of destruction, to fill this box with anything broken or damaged. But what if that box represented a collective 'black hole' where all the wounds, pain, suffering, and destruction would disappear, or might just stay trapped in the past, as if citizens were literally collecting these dark moments from their collective consciousness and throwing them away. They did not know where the black box was going, nor did they ask.

The impact of the explosion was significant. It completely annihilated the façades of most of the buildings on the street. Eventually, this initiated a reassessment of the existence of some structures, and also provoked the redesign of others according to the new circumstances. On a personal level, I witnessed this destruction first-hand, as I was completing my undergraduate

\footnotetext{
${ }^{2}$ Darius Bazargan, “Neighbours at War in Lebanon's Divided city of Tripoli," BBC News, Tripoli, Lebanon, 6 February 2013, http://www.bbc.com/news/world-middle-east-21336372.
} 
studies in architecture. While learning about construction and its practice codes, the destruction of architecture did not belong to any architectural discourse — it was a matter that architects should not investigate. In other words, until the site is cleared, and unless the ruins are discarded, the architectural project should not yet start. It seems that as soon as architecture is damaged or destroyed, it becomes merely a product of violence that should be removed, not a manifestation of a present condition that deserves to be critically analyzed and understood.

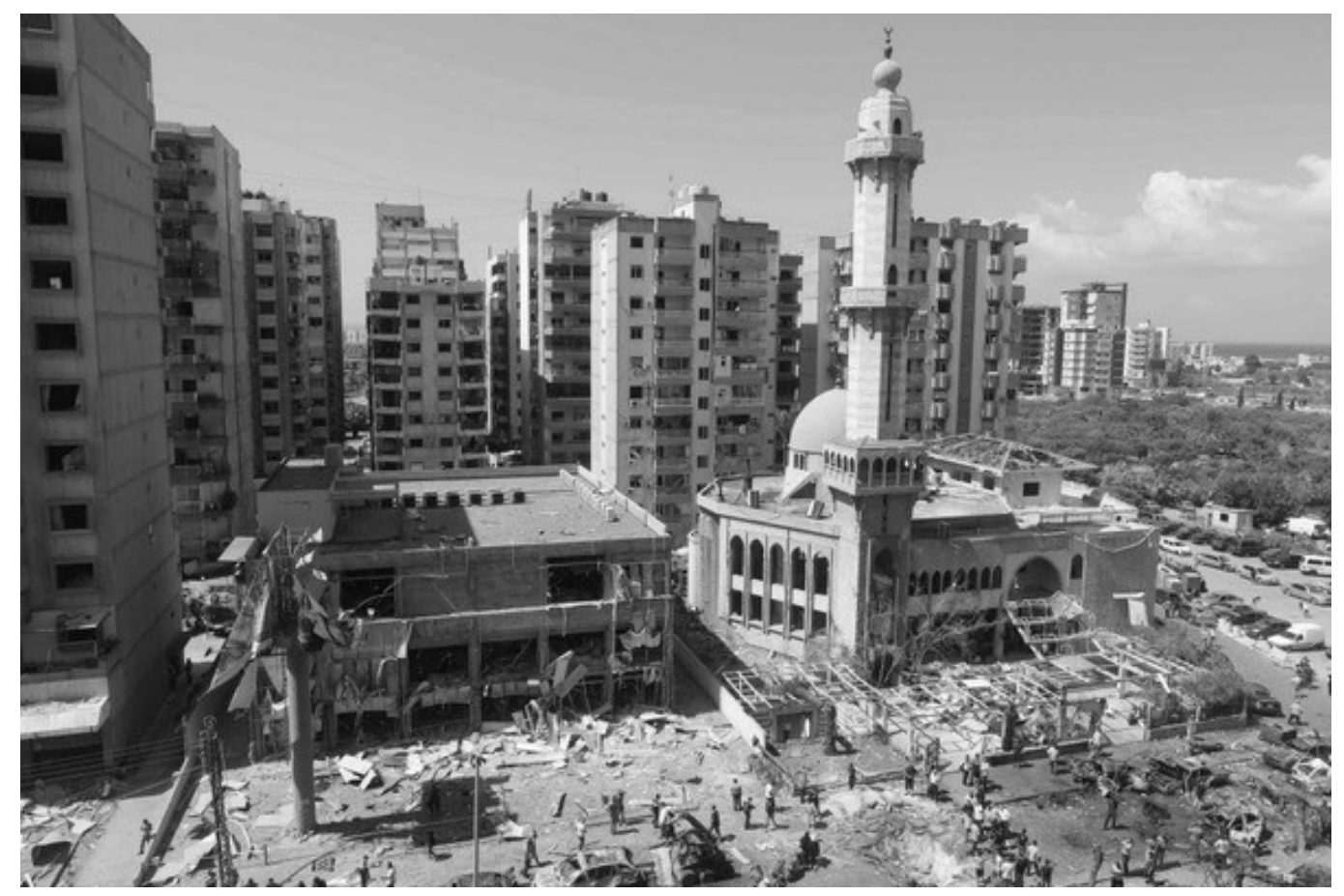

Figure 2: Jamal Saidi/Reuters. "The damage outside al-Salam mosque in the port city of Tripoli in northern Lebanon August 24. Bombs hit two mosques in Tripoli on Friday, killing at least 47 people and wounding more than 500, intensifying sectarian strife that has spilled over from the civil war in neighboring Syria." Source: http://www.csmonitor.com/World/Latest-News-Wires/2013/0824/Suspectarrested-in-Lebanon-double-bombing-death-toll-at-least-47

The destruction was left unexplained, an ambiguous phase that has to be quickly dismissed and removed. Violence was forced upon both the citizens and their architecture, and the experiences were powerful and real—they changed the lives of many and strengthened the 
sense of community. For me, this experience was an opportunity to perceive the simultaneous manifestation of life and death, a test of the extent and capability of willpower, and the experience of resilience. The destruction I witnessed initiated my break with conventional idealistic architectural norms that typically result solely in the conception of architecture as construction, and in perceiving this construction as a mighty structure embodying the celebration of permanent presence. This understanding of architecture perceives violence merely as an 'interruption' of the normal. In contrast, the violence that took place triggered critical questions about the severe consequences destruction can impose on architecture. It was not so much an interruption as a change, a 'turning point' worthy of investigation.

Is architecture merely neutral towards violence? In other words, does violence render architecture helpless and merely the recipient of destruction? This question represents the principal motivation for pursuing this research.

\section{"In everything that nature makes, nature records how it was made. In the rock is a record of how the rock was made. In man is the record of how man was made." 3}

Architecture records various accounts of violence, whether committed directly against it or around it. Façades are designed to express an intended dialogue between closed and open spaces, between opaque and transparent surfaces; they perform a play between plein et vide. Even though they are sometimes attacked and destroyed, the play remains, albeit with the inclusion of new elements: gaping holes instead of doors and windows, bullets and artillery shells colliding with concrete. Hence, the collision between architecture and violence might seem to create an 'ugly' scene, one of destruction and death. Nevertheless, this production does not

\footnotetext{
${ }^{3}$ Louis I. Kahn and Dung Ngo, Louis Kahn: Conversations with Students 26 Princeton Architectural Press (1998): 18.
} 
announce the end of the architectural project. Despite the fact that destruction severely injures architecture, it does not declare its death. Rather, this study suggests looking at it another way. Such a collision seeks a dialogue between different, if not opposing, realms, between life and death; in the words of Lebbeus Woods, "as equally vital elements of existence," ${ }^{4}$ between construction and destruction - these could be equal forms of architectural creation. But how can this sort of dialogue take place today?

\section{$*$}

Destruction of the built environment is dependent upon violence, since destruction is the physical exhibition of violence through space. When violence occurs, it is an exchange between two parties, the perpetrators of violence and its victims. As a result, the enemy's body - built, or breathing - will be destroyed. When architecture and violence meet, the destruction of buildings means the killing of people. Architectural traces of destruction left on buildings are witnesses of war crimes against people but also against architecture: The hidden trails of human suffering are embodied by the scars of destruction.

This study is divided into four chapters in an attempt to explore a triangle between humans, violence, and architecture. It starts with a philosophical discussion of violence and evil to understand violence in humans and their capability for destruction. Chapter two explores the relationship between the city and its architecture and goes on to the collision between violence and architecture. This collision is discussed in chapter three, based on Lebbeus Woods's approach to destruction and his definition of architecture. The last chapter recounts personal accounts of specific scenes of destruction to arrive at a theoretical intermediary between violence

\footnotetext{
${ }^{4}$ Lebbeus Woods, The Storm and the Fall (New York: Princeton Architectural Press, 2004), 18.
} 
and architecture, far beyond the usual questions: Who inflicted violence? What was destroyed and why was it destroyed? Architecture as destruction should - and will - be critically analysed.

To begin interpreting the relationship between architecture and violence, it is essential to shed light on the authors of violence: those who order destruction and those who perform it. How can ordinary human beings turn into machines that take orders, without any responsibility or guilt? Do they abandon thinking? To discuss violence, the research refers to Hannah Arendt. She witnessed violence, interpreted it and analysed a destroyer's mind. Arendt argues that violence can be seen as either rationally or irrationally engaged. The latter is considered unexplainable, a deviation from logic, while rational violence is widely interpreted as a means to achieve an end, and limited to a certain context. ${ }^{5}$ Political and military propaganda is often employed precisely to make the destruction of a city appear as self-defense or a military necessity. By destroying architecture, they impose severe changes on the urban order and the social life it sustains. Hence, the first chapter of this thesis is an attempt to understand how 'destroyers ${ }^{6}$ carry out brutal tasks and inflict violence on others.

In order to build a comprehensive approach towards destruction, it is crucial to establish why architecture is targeted, what is being lost and for what reason. The second chapter consists of a close reading of Aldo Rossi's Architecture and the City. Rossi defines architecture introducing the public to the theory of permanence, the meaning of monuments, and the concept of the 'locus.' This research aims to set these ideas as starting points for new theories about the relationship between architecture and violence. Nevertheless, Rossi's theory does not offer an

\footnotetext{
${ }^{5}$ Hannah Arendt, On Violence (New York: Houghton Mifflin Harcourt, 1970).

${ }^{6}$ According to the Oxford English Dictionary: "Destroyer" (noun) 1. "A small, fast warship, especially one equipped for a defensive role against submarines and aircraft. 2. Someone or something that destroys: the greatest destroyer of love and peace." Through this thesis, the word is used for its second meaning, someone who destroys.
} 
end in itself. Rather, it serves to augment the American architect Lebbeus Woods's theory of violence, introduced in the third chapter. Rossi and Woods belong to a generation of architects who matured right after the end of the Second World War. ${ }^{7}$ Despite the fact that Rossi does not refer to violence extensively, he describes the horrors of the destruction he witnessed during the Second World War, ${ }^{8}$ emphasizing the idea that loss due to destruction is not merely physical. In his book, he establishes the relation between form, meaning, and function in the city. Exploring this representation thus lays the groundwork for understanding what is really at stake when architecture is both attacked and destroyed, and grounds Woods's experimental ideas in a theoretical architectural frame. Consequently, chapter two provides an explanation for why architecture is targeted by analyzing what it represents to the city. The discussion reveals that it is the imperative to eradicate not just individuals but collective memories and identities that makes destruction a recurring tactic in wars against cities. Hence, architecture is destroyed because of what it represents. However, the perpetrators of violence tend to deliberately combine the fate of buildings with the fate of people. Before any destruction takes place, a process of 'defamiliarization' is often pursued in order to turn architecture into a 'destroyable' target. Therefore, violence, in other words, reduces architecture to a representation of a present situation that needs architecture as a supplement in order to manifest itself. Andrew Herscher explains this through the concept of 'warchitecture': as a war both on architecture and by architecture.

The devastation of architecture is connected with the suffering of the victims, in spaces that become slowly deprived of life, 'dead' spaces that presumably do not invite any critical

\footnotetext{
7 "For Rossi's generation, it was no longer possible to be a hero, no longer possible to be an idealist... No other generation had to follow such a sense of expectation with such a sense of loss."- Peter Eisenman, in the introduction to The Architecture the City (Cambridge, MA: MIT Press, 1982), 4.

${ }^{8}$ Ibid, 22.
} 
interpretation or interaction by their inhabitants. This destruction demonstrates both violence against architecture and violence against those who inhabit architecture. These spaces of crisis undergo radical changes both physically and socially—-the inhabitants experience new possibilities and unexpected challenges in their habitual spaces. Chapter three is an exploration of these 'spaces of crisis' where violence collides with architecture. The discussion consists first of the physical transformation that structures undergo after the first moments of destruction, and then the social transitions that take place in these spaces - including shifts in function and the creation of new experiences. This process is intended to inspire, in the terms of Lebbeus Woods, a 'radical reconstruction' as an attempt to answer the following questions: Can Architecture survive its union with destruction, the 'ugly' evidence of violence? And is architecture capable of transforming violence as much as violence transforms architecture?

These critical questions are addressed in the last chapter in an effort to combine Andrew Herscher's notion of 'warchitecture' with Lebbeus Woods' analysis of destruction through his own experience and witnessing of the war in Sarajevo. Rather than recounting Woods' description of violence against architecture, this research draws on my personal depictions of destruction - inspired by Woods' description of his experience - to visualize Herscher's theory by using different types of spaces in crisis. In other words, this attempt is sought as a simulation of Woods's experiments with destruction, not through drawings - as Woods does in Radical Reconstruction - but through words, based on Herscher's theory in Violence Taking Place. Through the notion of 'warchitecture', architecture does not merely promote construction - as a contradiction to destruction. Instead, destruction is included in the domain of architecture. Exploring the possibilities of changes in the built environment - following destruction - as base for reconstruction plans means that the boundaries can be collapsed between destruction and 
construction. It also proves that violence is not an interruption of urban life, rather, it can be a part of its progress.

The ideas this study explores, in the end, describe difficult human conditions. The gravity of such scenes of destruction may defy any possible explanation. Therefore, I ask my readers to truly consider these thoughts as a modest attempt to merge personal experience and academic research to rethink destruction in damaged and destroyed cities. Let us thus discuss space and architecture differently, and experience a type of space we haven't experienced before. To regard these architectural notions in "the spaces of crisis" as experimental helps to foster further discussion, and integrate imagination, new suppositions, and uncertainty into the arguments that come in the following chapters. Consequently, it hopefully also frees the author, and the readers, of the conventional limits that encourage prejudgment, and narrow our understanding of violence, space and architecture.

Beyond what is right and wrong, beyond what is expected and approved, there exists a space worth seeking... 


\section{First space. Constructing Destruction: The Perpetrators of Violence}

"City despisers and city destroyers haunt more than our books; they haunt our lives. From what depths of a misguided national spirit do they rise and where are they headed? On what muddled principles do they base their views? By what images are they obsessed and in what morbid books do they find them? Clearly in books that have nothing to do with history. For the savage has trouble grasping that anything could have existed before him." ${ }^{9}$-Bogdan Bogdanović

What kind of thinking takes place inside the mind of a destroyer that finds little or no hesitation in killing people and destroying cities? Once someone experiences moral collapse, it can initiate a total collapse of judgment: a man who kills one innocent soul may kill a hundred more, and may destroy a whole city; for him, scale is hardly an issue. This is the argument Jerusalem's court depended on in the trial of Adolf Eichmann. The prosecutor was attempting to prove that the accused killed a Jewish boy in his earlier years. ${ }^{10}$ Proving this crime established Eichmann's capacity for murder, and therefore his later affiliation in the Holocaust.

\section{Violence, Power and Evil}

A war between two human beings, two communities, two nations, or two continents is often triggered for the same reasons: the will to dominate and to govern. Philosopher Carl von Clausewitz defined war as "an act of violence intended to compel our opponent to fulfill our will." ${ }^{11} \mathrm{He}$ also characterized war as "a pulsation of violence,"12 and "the continuation of policy

by other means." ${ }^{\prime 13}$ In other words, war is a political instrument, and it can never be isolated from

\footnotetext{
${ }^{9}$ Bogdan Bogdanović, "Murder of the City," The New York Review of Books (1993).

${ }^{10}$ Hannah Arendt, Eichmann in Jerusalem: A Report on the Banality of Evil (London: Penguin, 1976), 215.

${ }^{11}$ Carl von Clausewitz, On War, ed, and trans. Michael Howard and Peter Paret (1976), chapter 1, section 2.

12 Ibid, chapter 1, section 23.

${ }^{13}$ Ibid, chapter 1 , section 24.
} 
its "political object." ${ }^{14}$ War is about governance, the use of violence instead of peace to address conflict. ${ }^{15}$ Nevertheless, it can also have an independent will that pushes policy aside and "rule by the laws of its own nature." 16 War thus resembles a duel, on a bigger scale. Clausewitz describes war theoretically, as a "paradoxical trinity" formed essentially from violence, hatred, and enmity. However, this trinity is also influenced by chance, probability, and the "element of subordination, as an instrument of policy, which makes it subject to reason alone." ${ }^{17}$ The first component in this trinity belongs to the people. The second is the army. The third component is the government, of course. Therefore, according to Clausewitz, there should always exist a balance among these three 'tendencies:' the feelings that should empower war are inherent in the people. The play of probability and chance depends on the technical skills and strategic plans of the army. The political decisions belong to the governments. ${ }^{18}$

In 1970, Hannah Arendt discusses the subject of war and violence extensively in her essay On Violence. In a clear critique of Clausewitz, she argues that in present times, these old views of Clausewitz about the relationship between war and politics, or violence and power, have become ineffective. ${ }^{19}$ Instead of war being an extension of diplomacy, "peace is the continuity of war by other means" is the common technique of warfare today. ${ }^{20}$ In fact, continues Arendt, "the technical development of the implementation of violence has now reached the point where no political goal could conceivably correspond to violence's destructive potential or justify its actual use in armed conflict." ${ }^{21}$ She goes on to say that "warfare has lost much of its

\footnotetext{
${ }^{14}$ Ibid.

15 "War," Stanford Encyclopedia of Philosophy, http://plato.stanford.edu/entries/war/ (accessed February 29, 2016).

${ }^{16}$ Clausewitz, On War, chapter 1, section 23

${ }^{17}$ Ibid., Chapter 1, Section 28

${ }^{18} \mathrm{Ibid}$.

${ }^{19}$ Arendt, On Violence, 9.

${ }^{20}$ Ibid, 3.

${ }^{21}$ Ibid, 3.
} 
effectiveness and nearly all its glamour." ${ }^{22}$ The world is playing according to the logic that no matter who wins, all parties will face peril. Hence, the goal is no longer victory; rather, deterrence is presented as a guarantee of peace. At the time the book was published, the world was witnessing the Cold War, the nuclear arms race, the American war in Vietnam, race riots, student movements in the West, and the peak of the Arab-Israel conflict-On Violence clearly reflects the 1960s. Nevertheless, somehow it seems as if the book could have been published today ${ }^{23}$ While reading Arendt, one can't resist but cast it on the world now and ask: What has changed? Arendt predicted it, with crystal clarity: "The practice of violence, like all action, changes the world, but the most probable change is to a more violent world. ${ }^{24}$

As Arendt states, we are headed towards a more violent world, where violence is both a means and an end in itself. A world where violence has become legitimate in the name of certain beliefs, or states, where its "implements" are stronger than ever, and where those in charge confuse power with violence. While Arendt repeatedly insists that violence and power are never equal, today, her commentary on these two terms is more relevant than ever. ${ }^{25}$ She argues that power relates to the capacity "to act in concert"; it applies to a group of people and does not belong solely to individuals. ${ }^{26}$ Somebody is in power because a group of people "empowered him to act in their name."${ }^{27}$ Power and violence, although separate notions, appear together, but Arendt asserts that power should be the dominant component.$^{28}$ However, it is not always the

\footnotetext{
${ }^{22}$ Ibid.

${ }^{23}$ Apart from the "racist" references to African-Americans. In her discussion of the student rebellion in America at that time, Arendt compared "black" and "white" student movements. She described the "black power movement" on campus as "violence of the black student," claiming that their interest was to "lower academic standards" because they were admitted "without academic qualifications." For her, their demands were "silly and outrageous." Ibid, 19.

${ }^{24}$ Ibid.

${ }^{25}$ Ibid, 43 .

${ }^{26}$ Ibid, 44.

${ }^{27}$ Ibid.

${ }^{28}$ Ibid, 52.
} 
case: "We saw that the current equation of violence with power rests on government's being understood as domination of man over man by means of violence." ${ }^{29}$ She discusses the question of violence, both in terms of society and human nature. Arendt's analysis of violence asserts that we cannot understand it merely by justifying and rationalizing its use in any conflict. According to her, considering violence as an extension of human nature is simply false. And neither is it the continuity of policy by force or power, as these are of an entirely different nature.

However, Arendt argues that violence can sometimes be justifiable if it is controllable and limited to self-defense — but it can never be legitimate. ${ }^{30}$ Those in power must understand that violence can and will destroy power, but that violence is unable to create power. ${ }^{31}$ Since, as she argues, it is ultimately true that "Violence appears where power is in jeopardy, but left to its own course it ends in power's disappearance. ${ }^{\prime 2}$ Once violence is used not as a means to an end, but as an end in itself, it destroys not only the target, but eventually its source.

\section{Accounts of Destroyers and the Destruction of Cities}

Violence always requires implements, and with the recent technological revolution warfare has taken on new dimensions. Over the course of the twentieth and early twenty-first centuries, the world has witnessed a great rise of new possibilities in the technical development of war. Destruction was no longer accompanied by humans actually going to a battlefield. War can now be fought at a great distance, and the "battlefield" could be an entire city. Today, aerial bombardment, missile attacks, and weapons of mass destruction are the new means of warfare. After thousands of years in which individual warriors suffered damage the most, the field, where

\footnotetext{
${ }^{29}$ Ibid.

${ }^{30}$ Ibid.

${ }^{31}$ Ibid, 56.

${ }^{32}$ Ibid.
} 
they literally faced each other, was the only land to be destroyed, the rules of the game have drastically changed. Civilians are now the victims who suffer the most, and highly populated cities are now the biggest battlefields.

To legitimize destruction and erasure of cities, "destroyers" tend to use deceitful propaganda to spread hope and eradicate genuine doubts and fear of the "system." For instance, in Germany, it was "nationalism, pure race"; in Serbia, progress and union, "for a Greater Serbia"; in China, it was "modernism via cultural revolution." It was simply false, it was no more than "evil," as Arendt said, hiding behind old notions and master plans that promoted simplified interpretations.

In The Destruction of Memory, Architecture at War, Robert Bevan states: "Between Stalin and Hitler a thousand years of architectural history had been laid waste in little more than ten." ${ }^{, 33}$ Hitler and Stalin may be the most famous "leaders in destruction," but they are not the only ones. Mao Tse Tung believed in "destruction before construction." His followers literally cleared the way for a new China. ${ }^{34}$ Historical and religious architecture was the primary target. Enforcing a new culture came with the systemized destruction of anything "old," anything that reminded people of the past. They were trying to form a new collective memory by erasing all the old ones. It was thought impossible until it was systematically carried out. ${ }^{35}$

Such enormous destruction happened again thirty years later in Bosnia. Branko Grujic, the Serbian mayor of Zvornik in 1992, during the 1992 Serbian massacres committed against the

\footnotetext{
${ }^{33}$ Robert Bevan, The Destruction of Memory: Architecture at War (Reaktion Books, 2007), 118.

${ }^{34}$ Ibid.

${ }^{35}$ Ibid.
} 
Bosnians, said: "There never were any mosques in Zvornik." ${ }^{36}$ A Serbian police officer told one reporter: "With their mosques, you must not just break the minarets. You've got to shake up the foundations because that means they cannot build another. Do that, and they'll want to go. They'll just leave by themselves." ${ }^{37}$ Indeed, they "will leave," in other words, whoever and whatever was there is not physically present anymore, so in consequence, there was nothing and there was no one... Such a denial of the other led to legitimizing the destroyers' supremacy, imposing a culture of "racial purity." To some extent, the perpetrators of violence were successful. However, the lies became so overwhelming that it became impossible to continue justifying their actions.

While Arendt in 1951 discussed state-endorsed violence in Origins of Totalitarianism, it was not until 1961 that she addressed the character and culpability of individuals who follow orders to carry out violent acts. That year, she travelled to Jerusalem to cover the trial of Adolf Eichmann for The New Yorker. Eichmann had been kidnapped and brought to trial by Israeli authorities. The accused was a Nazi S.S. officer in charge of the deportation of Jewish people to death camps during the Second World War. Arendt contacted The New Yorker and offered to work with them as a reporter and attend the trial as a journalist representing the newspaper. Her report was printed in the magazine and instantly received both widespread fame and harsh criticism. The controversial central argument was an unusual analysis of Eichmann's character and motives, which she characterized as "banal."

In her 1963 book Eichmann in Jerusalem: A Report on the Banality of Evil, Arendt argues that — contrary to what the world wanted to believe, or what is easier to assume - the

\footnotetext{
${ }^{36}$ Cited in The New York Times, 21 August 1992.

${ }^{37}$ Bevan, The Destruction of Memory, 46.
} 
monster behind the glass cage was no more than a normal man without any sadistic motives or psychological disorders. She portrayed Eichmann as a thorough yet "banal bureaucratic criminal." During the trial it was clear that "the longer one listened to him, the more obvious it became that his inability to speak was closely connected with an inability to think, namely, to think from the standpoint of somebody else." ${ }^{38}$ As if there were boundaries that shielded him from the outside world, Eichmann was living in a state of self-deception far from reality. He was not alone. Most of German society had been under the same self-deception, enabled by the lies embedded within and spread by Hitler's fascist regime. ${ }^{39}$

Perfectly normal individuals can be turned into destroyers, even though they are not completely ignorant of the gravity of their deeds. They may be perfectly aware of the consequences of their acts, but they fail to compare them with their inner judgment of 'good' and 'evil' and their attendant moral values. Instead of using 'killing,' 'destruction,' 'extermination"- - words long associated with evil activities - they used terms like 'final solution,' 'emigration,' 'special treatment,' 'deportation,' 'change of residence resettlement,' 'labor in the east,' as part of the system of "language rule." The Nazis used this coded language as an efficient shield against reality. Despite the fact that this was not a foolproof systemmeaning that the destroyers knew what these terms implied—few protested or refused to carry out orders. Arendt writes: "Not only Hitler, not only Heydrich or the 'sphinx' Muller, not just the S.S. or the party, but the elite of the good old civil service were vying and fighting with each other for the honor of taking the lead in these bloody matters. Who was he to judge? Who was he 'to have [his] own thoughts in this matter?" ${ }^{40}$ Eichmann, defending his deeds, said: "At that

\footnotetext{
${ }^{38}$ Arendt, Eichmann in Jerusalem, 49.

${ }^{39}$ Ibid, 52.

${ }^{40}$ Ibid, 114 .
} 
moment, I sensed a kind of Pontius Pilate feeling, for I felt free of all guilt.. ${ }^{, 1}$ How can thousands upon thousands of ordinary people become accomplices in violent acts, and in evil deeds? Do they give up thinking? Is it all due to our human nature? At this point, it seems pertinent to set the foundation for such dialogue by further exploring the concept of violence in human beings.

Arendt used Kant's theory of "radical evil" to describe the evil of the holocaust. However, she refused to attribute radicalism to evil. Good has depth; good can be radical. Evil can never be radical — it can only be extreme. And this is where the danger lies. It spreads easily over the world because it comes from a failure to think. ${ }^{42}$ The process of thinking, judging, and acting establishes moral boundaries and common sense to form a network of shared values. However, once this network collapses or even becomes corrupted, the whole process can deviate, and the ability to distinguish right from wrong is in danger of collapsing.

\section{Obedience to Authority, and Compliance to Violence}

In 1963, the same year Arendt introduced the "banality of evil" to describe Eichmann in her book, Stanley Milgram, a young social scientist published his studies in The Journal of Abnormal and Social Psychology. ${ }^{43}$ Milgram, born in 1933 to a Jewish family in New York, was deeply influenced by the holocaust and thus he closely followed the proceedings of the trial of Adolf Eichmann. ${ }^{44}$ In 1961, Milgram had carried out a psychological experiment at Yale University that shocked the world. Random people were asked to deliver "electric shocks" to a stranger strapped to a chair behind closed doors, in response to wrong answers to questions.

\footnotetext{
41 Ibid.

${ }^{42}$ See Amos Elon in the introduction to Arendt, Eichmann in Jerusalem, xiv.

${ }^{43}$ The importance of explaining his experiments resides in revealing that Eichmann and his Nazis superiors were not an uncommon case of humans turning into "monsters" (in the words of Arendt).

${ }^{44}$ Stanley Milgram, Obedience to Authority: An Experimental View (New York: Harper \& Row, 1974), 6.
} 
These shocks were fake, the person who was supposedly getting them was in fact the assistant of the experimenter, aware of the true purpose of the experiment, though the participants did not know that. They were told that the research aims to study memory and learning, but the experiment was really about obedience to authority. ${ }^{45}$

The level of obedience represented the intensity of electric shock the teacher (volunteer) gives to the student (Milgram's assistant) when he delivers a wrong answer. How far would they go? Would the teacher go all the way to the maximum electrical charge simply because they were told to do so? The series of experiments revealed both convincing and disturbing facts. Most volunteers asked whether they should carry on, sentences like: 'Please continue,' and 'The experiment requires that you continue' were used as a form of communication between the participants and the experimenter. ${ }^{46}$ Yale students and professors first predicted that only three percent of participants would complete the experiment. ${ }^{47}$

However, the truth was very different, as Milgram pointed out in a book about the study published in 1974, more than ten years after his first experiment. Out of 40 participants, 26 completed the experiment by administering the maximum shock $(450 \mathrm{~V})$, and 14 decided to step down before administering the highest "shock" levels. As disappointing and uncomfortable as it is, this means that $65 \%$-although many were stressed, hesitant, and even angry at the experimenter-kept on obeying sadistic orders from an authority figure, causing harm to an innocent subject. In explaining these results, Milgram declares:

Ordinary people, simply doing their jobs, and without any particular hostility on their part, can become agents in a terribly destructive process. Moreover, even when the destructive effects of their work become patently clear, and they are asked to carry out

\footnotetext{
${ }^{45}$ Stanley Milgram, "Behavioral Study of Obedience," The Journal of Abnormal and Social Psychology 67, no. 4 (1963): 371.

${ }^{46}$ Ibid, 374.

${ }^{47}$ Ibid, 375 .
} 
actions incompatible with fundamental standards of morality, relatively few people have the resources needed to resist authority. ${ }^{48}$

These findings, though controversial, still largely ring true until today. In 1999, Thomas Blass carried out new research concerning obedience, concluding that Milgram's findings are valid. ${ }^{49}$ In 2006, the experiment was replicated by psychologist Jerry Burger, and he arrived at nearly the same initial results as Milgram. ${ }^{50}$

Milgram asserts that the participants in the obedience experiments were not evil, sadistic human beings: "Indeed, it is highly reminiscent of the issue that arose in connection with Hannah Arendt's 1963 book, Eichmann in Jerusalem. [...] Somehow, it was felt that the monstrous deeds carried out by Eichmann required a brutal, twisted, and sadistic personality, evil incarnate. ${ }^{51} \mathrm{He}$ ultimately agrees with Arendt: "After witnessing hundreds of ordinary people submit to the authority in our own experiments, I must conclude that Arendt's conception of the banality of evil comes closer to the truth than one might dare imagine." 52 The participants in Milgram's experiment were ordinary human beings. They saw the person conducting the experiment as a higher authority who was ultimately responsible for their deeds. They chose to believe that completing their task would benefit science, and the person in charge of the experiment was a trusted scientist working in a trusted facility. In fact, most of the participants even asked who was responsible for the consequences if they carried on. For the most part, they were relieved

\footnotetext{
${ }^{48}$ Milgram, Obedience to Authority, 7.

49 Thomas Blass, "The Milgram Paradigm after 35 Years: Some Things We Now Know about Obedience to Authority," Journal of Applied Social Psychology 29, no. 5 (1999): 955-978.

50 "People learning about Milgram's $(1963,1965,1974)$ obedience studies often ask whether similar results would be found today. Ethical concerns prevent researchers from providing a definitive answer to that question. But my partial replication of Milgram's procedure suggests that average Americans react to this laboratory situation today much the way they did 45 years ago. Although changes in societal attitudes can affect behavior, my findings indicate that the same situational factors that affected obedience in Milgram's participants still operate today." Jerry M. Burger, "Replicating Milgram: Would People Still Obey Today?"American Psychologist 64, no. 1 (2009): 9.

${ }^{51}$ Milgram, Obedience to Authority, 6.

${ }^{52}$ Ibid, 7.
} 
and continued their "job" once they were told that no responsibility would fall on them—despite knowing that their actions were causing harm to another person. Notwithstanding the fact that the person conducting the experiment did not proclaim himself the "person in charge," people asked whether they should continue the experiment when they thought they should not.

As Arendt pointed out, the perception of authority was more powerful than thinking and moral judgment. Milgram concludes his experiment with this thought: "You could say we are puppets. But I believe that we are puppets with perception, with awareness. Sometimes we can see the strings. And perhaps our awareness is the first step in our liberation. ${ }^{.53}$ Human beings seem desperate to find a leader, someone to think for them and thus bear responsibility for their actions. We will create a figure of authority even if it does not exist. If a certain scientist can command a group of men to do as he says, Milgram concludes, one can only imagine what corrupt regimes and governments — with enormously superior authority and hidden intentionscan command of their citizens. ${ }^{54}$

\section{"Since it was possible, it was necessary" ${ }^{55}$}

In his final address to the court, Eichmann spoke of the redefinition of morals set by the government; for instance, the killing of Jews and other minorities was deemed ethically acceptable in the name of the German state, and so the killers were regarded as heroes. Eichmann mentioned Nazi meetings where high ranked officers proudly share drinks over conversations about their actions against Jews. ${ }^{56}$ Arendt claims that Eichmann was not foolish, although "[i]t was sheer thoughtlessness that predisposed him to become one of the greatest criminals of that

\footnotetext{
53 Ibid.

${ }^{54}$ Ibid, 95.

${ }^{55}$ French General Secretary General Secretary Jacques Soustelle on the development of the atomic bomb, May 1960.

${ }^{56}$ Arendt, Eichmann in Jerusalem, 114.
} 
period. [...] That such remoteness from reality and such thoughtlessness can wreak more havoc than all the evil instincts taken together which, perhaps, are inherent in man-that was, in fact, the lesson one could learn in Jerusalem.. ${ }^{, 57}$ She makes it clear that it was a lesson, not a theory. It is necessary within totalitarian regimes to create mere machines out of humans. The ultimate goals of these regimes require the ability to dehumanize. ${ }^{58}$ Thus, responsibility and guilt belong to nobody.

Jacques Ellul, who published The Technological Society in 1954, warned of the dangers of the loss of human control over the state and technology in the modern world. He argues that work is being fragmented and divided into small assignments, and that no one is responsible for the whole process. Everyone is attached to small, technical tasks, and are consequently under the illusion of being free ${ }^{59}$ For instance, a destroyer is certainly part of a society. He may be a soldier in a tank, a bureaucrat in his office, or an employee in front of his laptop. His task might be reduced to pushing a button, signing a paper, or accessing codes and numbers. As far as his conscience is concerned, he is only obeying orders that are presumably legal in his country, and while working to the best of his ability, he is thus serving his country. Considering the consequences of his acts, however, is not part of his job. His thoughts and actions are limited to the moment right before the execution of his task. Once the task is completed, he ought to move on to the next one. The task of assessing and judging consequences probably belongs to someone else who had nothing to do with the first part of the process. Thus, he brings his own assessment, judgments and actions to the situation - a situation he was not responsible for in the first place. Although Ellul talks about the technological society we are part of today, his insight becomes

\footnotetext{
${ }^{57}$ Milgram, Obedience to Authority, 288.

58 Arendt, Eichmann in Jerusalem, 114.

${ }^{59}$ Jacques Ellul and Robert King Merton, The Technological Society (New York: Vintage Books, 1964.)
} 
more apparent in times of war and violence, as technology has replaced the human body on the battlefield to perform military tasks and inflict violence quickly and more efficiently. To Ellul, technology has both empowered humans to become even more violent, and weakened their sense of responsibility and free will: "There is no longer respite for reflecting or choosing or adapting oneself, or for acting or wishing or pulling oneself together. The rule of life is: No sooner said than done. Life has become a racecourse $[\ldots]$ a succession of objective events which drag us along and lead us astray without anything affording us the possibility of standing apart, taking stock, and ceasing to act." ${ }^{\prime 60}$ This bleak assessment of modern technological societies echoes Arendt's analysis of Eichmann. The Nazis had the most advanced military technologies in the world at the time, and engaged as well in the most "evil" deeds and corrupt system of thought.

To believe in something often requires fighting for it even if it means destroying anything else that embodies a different truth. Who would hesitate from participating in war when it would protect lives and liberate the oppressed? Ellul describes the propaganda that encourages this line of thinking, which does not allow for questioning, evaluation or even discussion. For instance, such slogans as "war is a constructive phase, necessary to attain liberation" conceals the truth and pervades people's sub-conscious to see something evil as good. ${ }^{61}$ These ideas act to create a myth about war, a story that keeps it flourishing in the mind of the masses. If there were not such constant reminders, however, war would not endure the first bullet impact, nor the first corpses. The fact that it still does can be explained by Ellul, Arendt and Milgram. This also recalls philosophers who first discussed the possibility of violence as something inherent in humans, on one hand as a form of communication when other means are exhausted, and on the other in the

\footnotetext{
${ }^{60} \mathrm{Ibid}, 330$.

${ }^{61}$ In reference to Arendt's On Violence.
} 
process of following orders. The former describes the origin of the state of violence among human beings, while the latter describes state violence against both its citizens and enemies.

The destruction inflicted on a city may come from one order. However, as discussed above, the task is always fragmented into smaller pieces that become the duty of thousands of men, and the responsibility of none of them. The fatal consequences of violent acts brutally affect the lives of the citizens on the other side. Their spaces become violated, their architecture destroyed, their quotidian lives drastically changed. Home, workplaces, entertainment places, and religious spaces, etc, could be damaged or even destroyed. Memories will be created; some are kept, some are erased, and the city will never be the same again. 


\section{Second space. Architecture in the City: The Target of Destruction}

"Urban artifacts have their own life, their own destiny. "62 -Aldo Rossi

"Cities fall not only physically, as a result of outside pressure; they fall spiritually, from within." 63 -Bogdan Bogdanovic

After the above discussion of Hannah Arendt's theory on violence and her interpretation of the destructive acts of the perpatrators of violence, the study now asks why these perpetrators of violence make the destruction of architecture their main target when attacking cities. To understand the importance of destroying architecture, it is pertinent to understand the relationship between architecture and the city. Although Rossi does not elaborate on the specific relation between architecture and violence, he makes it possible to establish a basis for such a dialogue in two ways. First, he argues for the importance of form rather than function in understanding the relation of architecture to the city. Second, he emphasizes the "changes" that form might undergo, and then focuses on the meanings that reside in these forms. The question here is not whether form gives meaning to space, but rather, once the form is damaged or destroyed by violence, does it acquire additional layers of meaning or does it lose any of the meaning it originally had?

In The Architecture of the City, Rossi undertook the task of rationally dissecting a city and describing the role of its parts. ${ }^{64}$ However, he insists that the city should not be reduced to this or

\footnotetext{
${ }^{62}$ Rossi and Eisenman, The Architecture of the City, 101.

${ }^{63}$ Bogdanović, "Murder of the City."

${ }^{64}$ In the 1950s, Rossi started to investigate the relationship between architecture and the city, history and memory. In 1966, he published his first book in Padua at the age of thirty. Considered as one of the first major reassessments of the Modern Movement, The Architecture of The City is still considered as an important contribution to architectural theory, and has been translated to many languages across the world. The book is considered an
} 
any other single idea; rather, the totality and beauty of the city originates from various 'moments of formation.' It is authenticated in space and form, and measured in time. ${ }^{65}$ Each of these parts is marked by their own location, boundaries on the ground, and their 'physical presence. ${ }^{96}$

Rossi states that to contemplate the city itself as architecture "means to recognize the importance of architecture as a discipline that has a self-determined autonomy, constitutes a major urban artifact within the city, and, through all the processes analyzed in this book, links the past to the present. ${ }^{967} \mathrm{He}$ insists on the understanding of architecture as identified within the city, not without it. ${ }^{68}$ To consider the city as architecture also means that architecture should not be reduced or limited to a certain context or scale. In other words, architecture does not consist solely of fashionable buildings that celebrate economic power, nor mere housing solutions. Architecture's true meaning comes from every single building and its communication with its urban environment.

\section{Architecture: the 'soul' of the city.}

According to Rossi, architecture as a human-made product, as an independent field, and form as an element of permanence in it, constitutes the durability of the city over time, functioning as a node between past and present; indeed, the city is its history: "It is an event and a form. Thus, the union between the past and the future exists in the very idea of the city that it flows through in the same way that memory flows through the life of a person." ${ }^{69}$ Rossi argues

\footnotetext{
important record of Rossi's ideas and a window to understand his designs. The author developed a new theory of typology in the study of architecture and urbanism, based on his thorough contemplation of European cities such as Rome, Berlin, Milano, Padua, etc.

${ }^{65}$ Rossi and Eisenman, The Architecture of the City, 64.

${ }^{66}$ Ibid.

${ }^{67}$ Ibid., 165

${ }^{68} \mathrm{Ibid}, 170$.

${ }^{69}$ Ibid, 131.
} 
that cities are the locus of collective memory. Cities resemble memory by their links with places and objects. He notes that our idea of a building depends mostly on the memories we have of it as part of the collective. For instance, people who despise specific spaces might link them to frightening or unsettling moments in their lives, whilst others could possibly have brighter images of that same place. And so, the sum of these different experiences constitute the city. To Rossi, this is the âme de la cite, its raison d'être.

Rossi believes that architecture is a fixed platform for our human action, privately and collectively interacting with individuals in the city. He states: "Sometimes I ask myself why architecture is not analyzed in these terms - that is, in terms of its profound value as a human thing that shapes reality and adapts materials according to an aesthetic conception.. ${ }^{, 70}$ In empasizing shapes, materials and aesthetics, Rossi clearly stresses the issue of form and its meaning. However, he does not merely look at it from either a functionalist or a modernist point of view. For him, the city is the foundation of architectural types. In other words, consistency in the form of some building contributes to the creation of architectural types. However, the existence of the city is the reason these architectural types can be found in the first place. Thus, he argues that form and only form should be the subject of study because it persists through time and history, whereas the function, and the social values it carries, is subject to change for reasons outside of architecture. ${ }^{71}$ This means that Rossi very much criticizes architects who believe that form must always follow its expected function, and that architecture acquires its meaning by serving human needs.

\footnotetext{
${ }^{70}$ Ibid, 34.

${ }^{71}$ Chapter four will offer a detailed discussion of spaces switching functions, and an interpretation of spaces that suffered transition in relation to Rossi's theory on form and function.
} 
For Rossi, there is an emphasis on the 'individual personality' inherent to every city, a soul created by ancient traditions, emotions, and desires. Human beings are not merely inhabitants of one country and one city, but rather of a delimited space. Every urban change affects their lives, and their reactions to those changes are sometimes unpredictable. As well, human lives have their own specific meanings, even though they are all marked by birth and death, and so is the life of the city with its own architecture as a 'physical sign.'

\section{Architecture: Encountering Violence}

Rossi highlights the experience that architecture creates in the city. Every individual experience is delineated by physical boundaries, and the sum of all these experiences constitutes part of the city as a whole. Each building has its own 'locus' within the city. Determined by space, time, topography, form and by witnessing the sequence of ancient and recent events, the locus is in itself a site and an event. In the introduction to Rossi's book, Peter Eisenman explains Rossi's approach, clarifying that since the city is a "theater of human events" 72 containing actions and feelings, those events carry memories of the past, but also ideas about the future. Thus, buildings act as signs of events that took place on a specific site, creating links between space, events and signs. Eisenman continues: "The locus may be said to be the place on which architecture or form can be imprinted. Architecture gives form to the singularity of place, and it is in this specific form that the locus persists through many changes, particularly transformations of function." ${ }^{.73}$ These transformations of function alter the way that architecture is seen, used, and experienced. However, despite these changes, the locus persists through time and memory—and these changes are often the result of violence.

\footnotetext{
72 Ibid, 7.

${ }^{73}$ Ibid.
} 
According to Rossi, the only element that is fixed in the urban dynamic is the monument, which conveys the essence of collective memory. ${ }^{74}$ The different layers of the city are irreversible and specific patterns, creating the primal and eternal fabric of life. He also argues that to understand the elements that compose the city and its essence, it is enough to look at an image of a city that has experienced violence, of shuttered houses where the inside and the outside were brutally reversed. ${ }^{75}$ Rossi also compares the transformations that happen to architecture and the changes that occur in people's lives. In his observation of the horrific destruction of World War II, he writes:

Anyone who remembers European cities after the bombings of the last war retains an image of disemboweled houses where, amid the rubble, fragments of familiar places remained standing, with their colors of faded wallpaper, laundry hanging suspended in the air, barking dogs - the untidy intimacy of places. And always we could see the house of our childhood, strangely aged, present in the flux of the city. ${ }^{76}$

The violence he describes is a recurrent form of change that architecture suffers from; for him, this change affects architecture as much as the human life around it. Amidst the wreckage, fragments of familiar spaces remain after being visited by violence and chaos. These images of destruction also convey how much the destiny of the individual is affected as part of the destiny of the collective. ${ }^{77}$ However, Rossi paints a 'romantic', or perhaps a poetic interpretation of architecture in the city and when talking about destruction, he creates a nostalgic description of ruins and intimate spaces. He does not go further in explaining his views on architecture and violence.

\footnotetext{
${ }^{74}$ Ibid, 22.

${ }^{75}$ European cities after World War II, Asian cities in Vietnam (1959-1979), Afghanistan (2001-2014), Iraq (20032011) after the American invasion, and Lebanon after the civil war (1975-1990).

76 Ibid, 22.

77 Ibid.
} 
Violence in architectural discourse is not commonly addressed by architects. Andrew Herscher ${ }^{78}$ argues that one reason could be that architecture is considered to promote construction ${ }^{79}$ - the art of building. Ruins and destruction do not belong to the planning process, and the design must start as soon as the site is 'cleared.' Once the signs of the destruction of previous structures have been removed, construction can begin to give new meaning to a site. Whatever existed and is now damaged or in ruins loses its 'right' to be understood and have meaning. However, this conception of architecture cuts off any real conversation between violence and architecture and limits it to a simple relation of cause and effect.

\section{Architecture: The Representation of Culture/Target/Physical Reminder}

In The Destruction of Memory: Architecture at War, architect/journalist Robert Bevan argues that the systemized eradications of certain types of buildings (churches, mosques, libraries) are often carefully executed to erase a cultural identity. Buildings and neighbourhoods are often targeted to exterminate ideas that go beyond military strategy. Indeed, war is not concerned solely with destroying infrastructure, burning residential buildings, and killing people. Rather, war targets culture, and the collective memories that people share and cherish. Those memories, along with the walls they inhabit are, to Bevan, the last 'reminder' of a people's existence ${ }^{80}$ Collecting stories from all over the world, the book serves as an account of the

\footnotetext{
78 "Andrew Herscher is a writer and a professor at Stanford University. His work explores the architectural and urban media of political violence, cultural memory, collective identity, and human rights, focusing on modern and contemporary Central and Eastern Europe. He has been particularly involved in the Balkans, where he has worked as an investigator and expert witness on the war-time destruction of cultural heritage. His book, Violence Taking Place: The Architecture of the Kosovo Conflict, was published by Stanford University Press in 2010". - Canadian Centre for Architecture.

${ }^{79}$ Andrew Herscher, Violence Taking Place: The Architecture of the Kosovo Conflict Stanford University Press, 2010.

${ }^{80}$ This conflict in representation between Bevan and Herscher will be covered next in the chapter.
} 
atrocities of war and violence, as well as the destructive effects they have on architecture and culture.

He points to the Nazi's destruction of many German synagogues on Kristallnacht, the Croatian attack on the sixteenth-century Ottoman bridge at Mostar, and the destruction of the National Library of Sarajevo by the Serbians — each site faced an enemy who methodically planned not only the destruction of infrastructure or buildings of political importance, but targeted specific structures that affirm the culture of a people and the ideas they share. They knew that people are replaceable, but their culture was not. ${ }^{81}$

In Bevan's logic, when people and their buildings become one in ideological terms, then it is not sufficient anymore for perpetrators of violence to take only lives, by denying the past and erasing the present — they also want to control the future. Shared places, experiences and memories lead to collective identities and the formation of traditions. So specific and meaningful sites of culture are targeted and destroyed. One shocking scene in Bevan's book is that of a librarian watching the Sarajevo Library burning. The air was filled with dust, and gray ashes of papers, "catching a page you can feel its heat and for a moment read a fragment of text in a strange black and grey negative, until, as the heat dissipated, the page melted to dust in your hand." ${ }^{82}$ However, is architecture merely a representation and a symbol of culture, as Bevan seems to present it? And is the meaning of architecture reduced merely to "physical reminders"?

In Violence Taking Place, Herscher argues that perpetrators of violence tend to combine the fate of buildings with the fate of people. They sometimes deliberately enforce the idea that certain architecture in a certain place represents certain people, thus legitimizing violence against

\footnotetext{
${ }^{81}$ Bevan, The Destruction of Memory, 28.

${ }^{82}$ Kemal Bakarsic, "The Libraries of Sarajevo and the Book that Saved our Lives," The New Combat: A Journal of Reason and Resistance (1994): 13-15.
} 
architecture. So, for Herscher, architecture's representation is not as simple and direct as Bevan presents it. He refutes the notion of architecture as a physical reminder of culture, referring to Jacques Derrida's interpretation of representation. ${ }^{83}$ Herscher argues that representation renders architecture a target (in the case of war), or an identity symbol (in the case of ethnic cleansing), and so destruction in both cases is an inevitable, predictable performance of force, reproduced time and time again throughout history. ${ }^{84}$ Violence becomes a form of representation: deformed structures, buildings on fire, scattered ruins are scenes produced and used by the authors of violence, its victims, and witnesses.$^{85}$ According to Herscher, this notion entails another one: architecture holds a representational status amidst its destruction. In other words, violence reduces architecture to a mere demonstration or representation of a 'presence' — of war and violence - that exists before architecture, and also without it. This presence uses the 'adequacy' of architecture as its manifestation.

For Herscher, there exists a dialectic between different notions of representation: architecture as a physical reminder and architecture as permanence. Robert Bevan asserts that architecture is a physical reminder or a symbol of a certain culture, and so architecture is targeted because it represents a certain people. ${ }^{86}$ At the same time, it holds a presence that is expected to outlive its builders and users. This 'permanence' is cherished throughout time, from ancient civilizations to the present time: People build and have built to be remembered, to defeat death by leaving a mark of their presence.

\footnotetext{
${ }^{83}$ Herscher, Violence Taking place, 81.

${ }^{84}$ Ibid, 6.

${ }^{85} \mathrm{Ibid}, 82$

${ }^{86}$ Bevan, The Destruction of Memory, 8.
} 
Architecture as a reminder is and should be - as Herscher argues - distinguished from the notion of its permanent presence. However, once it becomes an object of destruction and violence, it is linked directly with this presence and thus attacked because of it. In other words, people are both outlived and represented by architecture, and architecture being destroyed as a representation (and a reminder of those people), so ultimately the destruction of architecture destroys the people (who are supposed to be represented). Thus, architecture here seems to be both distinguished from, and identified with, the object of its representation.

Herscher refers to Derrida to explain this "paradoxical status," he described the notion of representation as a "supplement," meaning a nonessential addition to something that already has a full presence. To Herscher, the misconception of representation consists in the fact that it does not create anything but represents something that existed before and continues to exist without this supplement. ${ }^{87}$ In explaining the destruction and reconstruction in Kosovo, Herscher states: "Architecture could be destroyed as the property of a despised ethnic other or preserved as the property of a multiethnic polity, but in each case ethnicity did not stand outside of architectural reference as much as it was completed and confirmed by means of that reference. ${ }^{988}$ Each scenerio thus needs architectural completion in order to legitimize its presence. But it seems that the fate of architecture is always controlled by the representation imposed on it, and this representation is subject to change according to certain circumstances and contexts.

\section{'Warchitecture'}

Herscher believes that architecture is not merely destroyed for the purpose of destroying what it represents, but rather to force architecture to represent something in the first place, so that

\footnotetext{
${ }^{87}$ Herscher, Violence Taking Place, 82.

${ }^{88}$ Ibid, 151.
} 
architecture becomes always available to destruction. An intense transformation will happen first for the purpose of making a building a target and reducing it to ruins: "The tenements of Dresden and paper and wood homes of Tokyo must become housing for workers in war industries for them to be fire bombed; refugee camps in Palestine must become nodes of a terrorist infrastructure for them to be bulldozed; neighborhoods in Baghdad must become breeding grounds of insurgency for them to be managed as war zones." $\$ 99$ These labels of violence imposed on architecture are often mobilized by state or party propaganda to sell the idea of architecture as a threat. This guarantees the acceptance of war and violence against architecture.

However, for Herscher, the notion of 'warchitecture' is a reminder that what is being posed in "legitimizing accounts of violence as disembodied and abstract 'targets" 90 is, in the end, architecture itself :"objects and spaces for living, for the living. Framed as 'warchitecture,' the violence that these accounts neutralize can be reconstituted, an essential preliminary to responding to and opposing this violence. ${ }^{.91}$ Herscher here insists on the capacity of architecture to be used in resisting and responding to violence. But before this, a necessary, response to violence is to register this destruction so it can be comprehended and critiqued. ${ }^{92}$

Herscher explains that the term 'warchitecture' was created by Sarajevo's Association of Architects as a title of an exhibition ${ }^{93}$ in Sarajevo in 1993, during the four years (1992-1996) when Sarajevo was under siege by the Bosnian Serb army. The participants in the exhibition used the the visual techniques of architecture to register and document the destruction in

\footnotetext{
${ }^{89}$ Andrew Herscher, "warchitectural Theory," Journal of Architectural Education 61, no. 3 (2008): 35-43.

${ }^{90}$ Ibid.

${ }^{91}$ Ibid.

${ }^{92}$ Ibid.

${ }^{93}$ Herscher, Violence Taking Place, 83.
} 
Sarajevo. First, they located damaged zones in buildings (façades, roofs) ${ }^{94}$ Second, they analysed the effect of damage on the structures using the following typology: partial hit, complete hit, interior/exterior burning, complete destruction of building, etc. Next, Herscher explains that they "inserted the targets of this damage into a new architectural history of Sarajevo, a history that was composed in terms of the received historical-cultural categories (Ottoman, Austro-Hungarian, modernist, and contemporary) but whose architectural exemplars were all in varying states of war-induced ruin." ${ }^{.95}$ For these architects, the outcome of their analysis reveals a war on architecture, which they regarded as a war on culture, memory, and history—another enlistment of architecture as merely an expression of a present situation. ${ }^{96}$ 'Warchitecture', for them reflects this meaning.

However, Herscher clarifies his use of the term in his book Violence taking place: "I appropriate the term 'warchitecture' to foreground this recruitment of architecture as a manifestation of a presence. ${ }^{.97}$ For him, the term has an additional meaning that turns it into a theory. 'Warchitecture' theory for Hersche represents the possibility of a war engaged both on and by architecture, and asserts a statement that violence requires architecture as a 'supplement.' In other words, in the midst of its destruction, architecture is formed again and again, or recreated each time it falls.

\footnotetext{
${ }^{94}$ Ibid.

${ }^{95}$ Ibid.

${ }^{96}$ Ibid.

${ }^{97} \mathrm{Ibid}, 82$.
} 


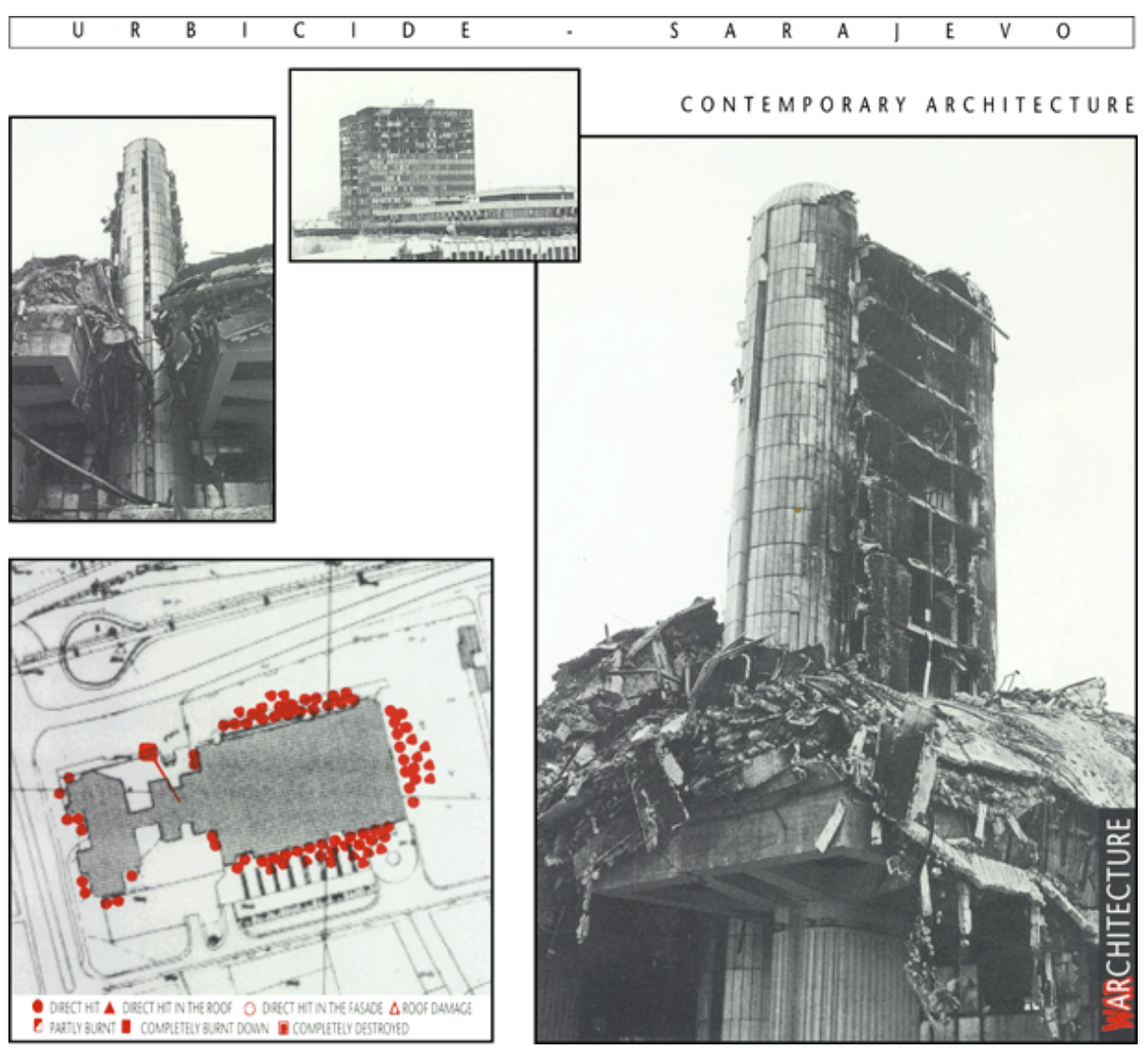

Figure 3 Warchitecture exhibition. Source: Journal of Architectural EducationVolume 61, Issue 3, pages 35-43, 10 JAN 2008http://onlinelibrary.wiley.com/doi/10.1111/j.1531314X.2007.00167.x/full\#f7

For Herscher, the theory of 'warchitecture' suggests that architecture does not merely promote construction in the limited senses of the word - as merely a contradiction of destruction, instead, through 'warchitecture,' destruction is included in the domain of architecture, and thus as Herscher suggests it cannot be diminished "to its contexts, nor to the intentions of its authors, nor to its effects on its targets." ${ }^{98}$ By admitting this, any claim of an objective relation between architecture and destruction is consequently dismissed. By collapsing the boundary between construction and destruction, the notion of 'warchitecture' allows for a rich explanation beyond the limited debate between irrational destruction versus rational destruction.

\footnotetext{
${ }^{98}$ Herscher, "warchitectural Theory," 35-43.
} 
"Architecture and Violence: Between Representation and Exchange" | Jenan Ghazal

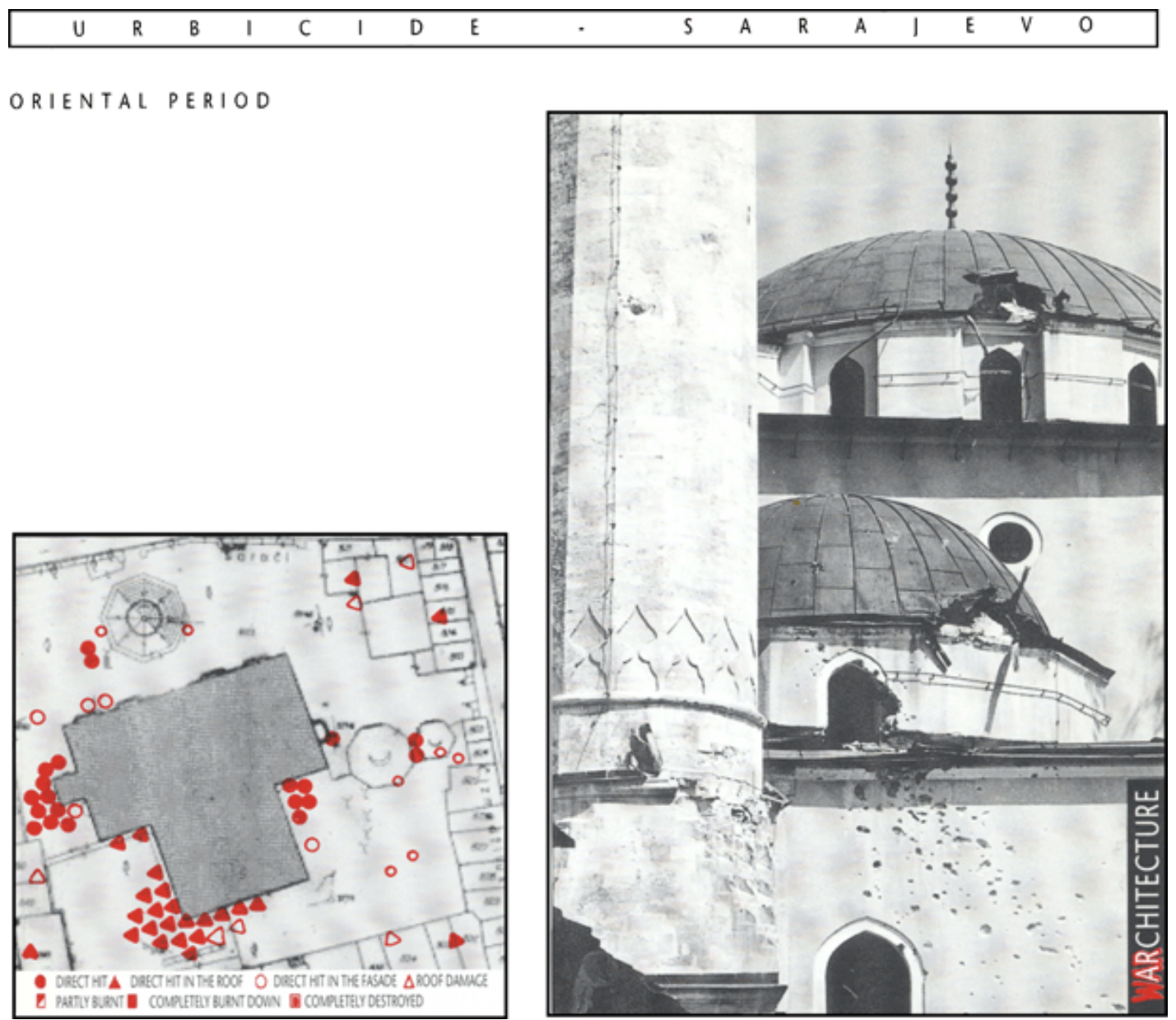

Figure 4: Destruction of Gazi Husrev-beg Mosque, Sarajevo (c.1994 by Asocijacija arhitekta DAS-SABIH,

Warchitecture: Urbicide Sarajevo). Source: Journal of Architectural Education Volume 61, Issue 3, pages 3543, 10 JAN 2008 http://onlinelibrary.wiley.com/doi/10.1111/j.1531-314X.2007.00167.x/full\#f6 


\section{Third space. Beyond Destruction, Lebbeus Woods.}

"Architecture and war are not incompatible. Architecture is war. War is architecture. I am at war with my time, with history, with all authority that resides in fixed and frightened forms. I am one of millions who do not fit in, who have no home, no family, no doctrine, no firm place to call my own, no known beginning or end, no "sacred and primordial site." I declare war on all icons and finalities, on all histories that would chain me with my own falseness, my own pitiful fears. I know only moments, and lifetimes that are as moments, and forms that appear with infinite strength, then "melt into air. "I am an architect, a constructor of worlds, a sensualist who worships the flesh, the melody, a silhouette against the darkening sky. I cannot know your name. Nor you can know mine. Tomorrow, we begin together the construction of a city." ${ }^{99}$ _ Lebbeus Woods

Lebbeus Woods published his book Radical Reconstruction in 1997— the same year Aldo Rossi passed away. Although formally distinct, their work shares two points that help in formulating a critical discourse on architecture and violence. First, both understand architecture as a temporal phenomenon - as something that must be understood to transform and come into being through time. Second, both architects emphasize form - not program - as the essence of architecture and the city. Introducing Woods' theory on violence and architecture in this chapter will build on Rossi's interpretation of architecture in the city, and work in parallel with Herscher's 'warchitecture' theory.

Among those who concur with Herscher is the experimental architect Lebbeus Woods. He argues that architecture is an embodiment of knowledge. The complexity of the structures, the streets, and thus the city are all formed over time and across the span of uncountable lives, thus

\footnotetext{
${ }^{99}$ Woods, Lebbeus. Pamphlet Architecture 15: War and Architecture. No. 15. Princeton Architectural Press, (1993):1.
} 
destruction of these complex layers of meaning is worthy of focus and analysis. It should not be regarded as an interruption of construction.

\section{Architecture: Knowledge/Matter, Order/Chaos}

Lebbeus Woods is an American architect and theorist who fought for a new understanding of architecture — an architecture that advocates process over product. For Woods, imagination, freedom, chaos, reason, and memory are all components of the "architecture of the now." ${ }^{100} \mathrm{He}$ called for a different world, one in which the architect's main duty is to think first. Thoughts must come before anything is done. Woods affirms that "architecture is first and foremost, a process of creating knowledge. Because of this, the making of architecture is a major coalescing activity in society, bringing together many flows into a single complex stream. In classical terms, architecture is a socially significant synthesis of the old antitheses: public/private, art/science, capital/ labor."101

In societies ruled by authoritative bodies demanding external foundations for securing their existence, objective knowledge is materialized by hierarchical architecture (public institutions, monuments) while subjective knowledge is found only in personal and private projects, which might be considered as works of art. For Woods, these are the 'heterarchical' structures. ${ }^{102}$ However, societies are continuously changing. Hierarchies are increasingly becoming devalued, and fixed authorities are crumbling, along with their monumental

\footnotetext{
${ }^{100}$ Woods constantly tested the conventional relation between form and function, and as his proposals were never final in his mind, they were always opportunities not statements of achievement. Woods's drawings depict a dynamic vision of architecture, constantly changing, quickly adapting to any new environment. The drawings raise awareness of every detail in the making of the concept, which focuses first on the materialization of ideas, and then expression of form.

${ }^{101}$ Lebbeus Woods, Alexandra Wagner and Michael Menser, Radical Reconstruction (New York: Princeton Architectural press, 1997), 14.

${ }^{102}$ Ibid.
} 
architecture. Today, the social order contains both fixed and fluid structures, the hierarchical and the 'heterarchical,' as Woods calls them, which co-exist. 'Heterarchical' structures always tolerate the hierarchical—but not vice versa. ${ }^{103}$ In fact, ideologies, as expressions of hierarchies, often overpower the 'heterarchical' using fear, abuse of power, war, and violence. In the introduction to his book Radical Reconstruction, Alexandra Wagner asks: "what else but destruction can arise from war? The enemy's memory must be erased, its bodies—built or breathing-humiliated." ${ }^{104}$ For Woods, this attempted erasure becomes part of the city. Thus, the scars of destruction should not be erased and treated as if nothing took place, as erasure means denying the history of what happened. The countless stories of war and violence, destruction and loss, are ever-present scars, both on human bodies and damaged buildings. ${ }^{105}$ They are worthy of serious interpretation to understand the impact of war and violence on architecture, the destruction cities suffer from, the extreme conditions that citizens experience; and the transformations that buildings go through.

\section{Woods' interpretation of War and Architecture}

In Radical Reconstruction, Woods tells the story of three 'spaces of crisis' based on personal experience. ${ }^{106}$ The book is a collection of Woods' original sketches and drawings of three projects in three different cities: Havana, San Francesco, and Sarajevo. Before Radical Reconstruction, he published Pamphlet 15: War and Architecture in 1993. He read his opening "aloud on the steps of the burned-out Olympic Museum in Sarajevo on November 26, 1993, in

\footnotetext{
103 Ibid.

104 Ibid, 10.

105 Ibid, 4.

${ }^{106} \mathrm{He}$ expands on the relation between war and architecture (Sarajevo), natural disasters (San Francesco) and revolution and architecture (Havana). The book expands his pamphlet War and Architecture from fifteen years previous. Combining a powerful expression of thought with a critical understanding of architecture, Woods deeply challenged the traditional understanding of reconstruction.
} 
full view of Serbian snipers and artillery gunners." ${ }^{107}$ Woods describes his experience in Sarajevo stating:

The towers are burned now in Sarajevo. The steel and glass monuments to enlightened progress in an age of industrial society are gutted hulks and with them the ideologies they embodied. Sarajevo's skyscrapers were prime targets of gunners in the hills together with minarets and domed mosques, the great library, the post office, the university buildings, and all others that symbolized reason and its promise of humane civil life. ${ }^{108}$

To justify his emphasis on the destruction of architecture, Woods sets up a comparison between war and architecture. He argues that architecture does not merely stand for buildings and artifacts; it performs ideas, and is an embodiment of order, not merely the organization of space. Architecture makes present what is "un-present," or rather, what could be perceived as absence. Woods believes that architecture is the conjecture of the visible and the invisible in a "thing." The invisible is the essence, meanings, experiences, memories, or knowledge. The visible is solid, that which exists in the here and now, in itself without transcendence. ${ }^{109}$

War, however, is the destruction of space, time, and memory. ${ }^{110}$ According to Woods, although considered as the lowest form of human interaction with the environment, war remains central to the history of humanity and social change, and it has long-term consequences for the built urban space, as well as the human life central to it. War reshapes and alters architecture. It reduces the existing patterns, through violence, to a ruined pattern that can't be replaced or restored in a single step. For Woods, this destroyed pattern is the result of a concentrated human effort, it needs to be analyzed and comprehended.

\footnotetext{
${ }^{107}$ Lebbeus Woods, The Sarajevo Window, 2 December 2011, https://lebbeuswoods.wordpress.com/2011/12/02/war-and-architecture-the-sarajevo-window.

${ }^{108}$ Lebbeus Woods, Pamphlet Architecture 15: War and Architecture, Princeton Architectural Press (1993), 3

${ }^{109}$ Ibid.

${ }^{110}$ Ibid.
} 
"Architecture and Violence: Between Representation and Exchange" | Jenan Ghazal

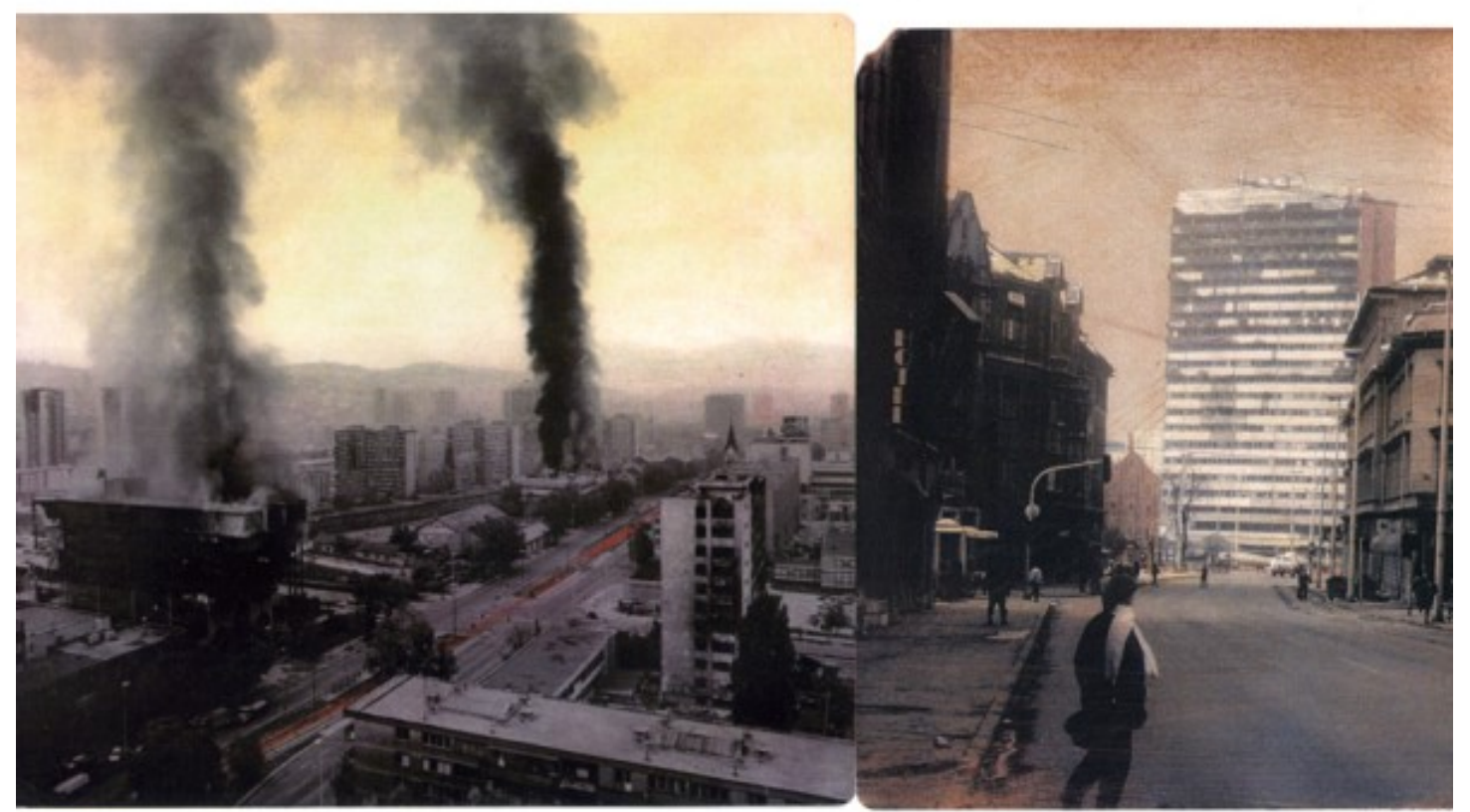

Figure 5: Lebbeus Woods. The burning Electrical Management Building, and (right) the badly damaged, but salvageable Parliament of Bosnia and Herzegovina. Source: Lebbeus Woods's blog. https://lebbeuswoods.wordpress.com/2011/12/15/war-and-architecture-three-principles/

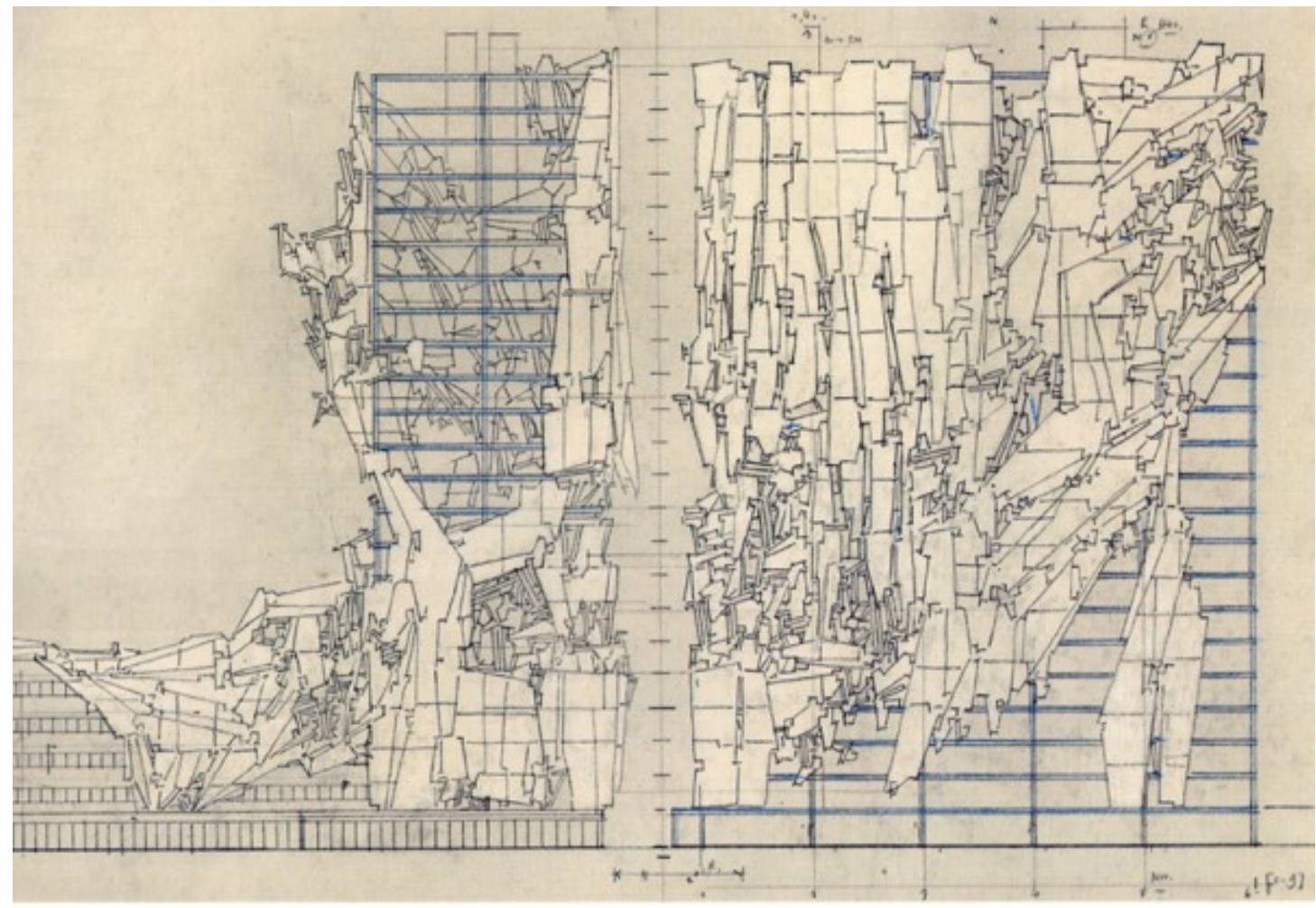

Figure 6: Lebbeus Woods, "New types of spaces woven into the surviving Cartesian structural frame, create a dialectic between timeless and time bound, a network of the unknown that inspires both dialogue and innovation." Source: Lebbeus Woods' blog. https://lebbeuswoods.wordpress.com/2011/12/15/war-and-architecture-threeprinciples/ 


\section{Destruction/ Reconstruction: New Concepts of Engagement}

Architecture speaks to the spectator through its own language; its presence is not supposed to be altered to reflect eventually a mere neutrality. According to Woods, there is no such thing as 'neutral space', in reference to Rossi, function does not define the nature of a place — only form can. ${ }^{111}$ Ultimately, architecture does not derive its meaning from its function; the meaning of architecture is found within its walls. ${ }^{112}$ Destruction changes not only the urban tissue but also the social fabric; architecture should be able to manifest this change.

In Woods's architectural logic, cities that have been destroyed by a human act, or by nature, should not be forced to return to their previous state as if there had been no violent intervention. ${ }^{113}$ Doing so means erasing the history of what happened; instead, these buildings should express what they went through. Shattered walls, roofs, and floor structures created by explosions and fires are complex forms, unique in their history and meaning. ${ }^{114}$ Expanding on this, Woods argues that:

Wherever buildings are broken by the explosion of bombs or artillery shells [...] their form must be respected in its integrity, embodying a history that can never be denied. In their damaged state they suggest new forms of thought and comprehension, and new conceptions of space that confirm the potential of the human to integrate with the building, to be whole and free outside of any predetermined, totalizing system. ${ }^{115}$

In these spaces voided by destruction, new structures are possible, forming spaces within other spaces, gaps between what is damaged or destroyed and what is not. According to Woods, these spaces are emotionally charged environments; whatever existed obtains new meanings and

\footnotetext{
${ }^{111}$ Rossi and Eisenman, The Architecture of the City.

112 Woods, Radical Reconstruction, 15.

113 Ibid.

114 Ibid, 16.

115 Joseph Becker and Jennifer Dunlop Fletcher, “Lebbeus Woods, Architect,” Drawing Papers 114 (2014): 15.
} 
value, and whatever exists experiences new change. Both what has been lost and gained exist as scars of pride and pain. ${ }^{116}$

In the end, established orders come and go, though cities still remain, however altered. Public spaces, used and re-used, acquire complex layers of meaning through their history, forming a living tissue that embraces its scars as signs of healing and resilience. To embrace the scar is to embrace existence. It is certainly not easy to be reminded of hurtful events, and it is also understandable for someone who has experienced war to want to remove every last trace of it. However, hiding the scar does not cause it to disappear. Its existence cannot be reversed, but it can be turned into an opportunity for learning, as well as a new beginning. Accepting the scar does not mean celebrating it, but starting on the road to healing. ${ }^{117}$

When talking about the situation in Sarajevo during the siege, Woods declared: "It was clear that architecture was part of the problem - the killing of thousands of innocent men, woman, and children — and I felt strongly that as long as the attacks continued, architecture also had to be part of the solution." 118 Healing cannot be reached through "cosmetic" processes executed on buildings. People should be able to see and feel the change, to finally be able to accept it, cherish it and eventually overcome the violence that took place. ${ }^{119}$

Therefore, emphasizing the destruction of architecture does not simply imply the material or physical condition of buildings, but rather the additional layers of meaning that gather around and between them: a bullet hole in a stone wall, a layer of dust on a window sill. ${ }^{120}$ It is by

\footnotetext{
${ }^{116}$ Ibid.

${ }^{117}$ Woods, Radical Reconstruction, 14.

118 Woods, "The Sarajevo Window."

119 Woods, Radical Reconstruction, 16.

${ }^{120}$ Woods, Radical Reconstruction, 16.
} 
focusing on these elements that we can tell the stories of the buildings and the transformations they've been through. Though difficult, this perhaps can be a path to resilience.

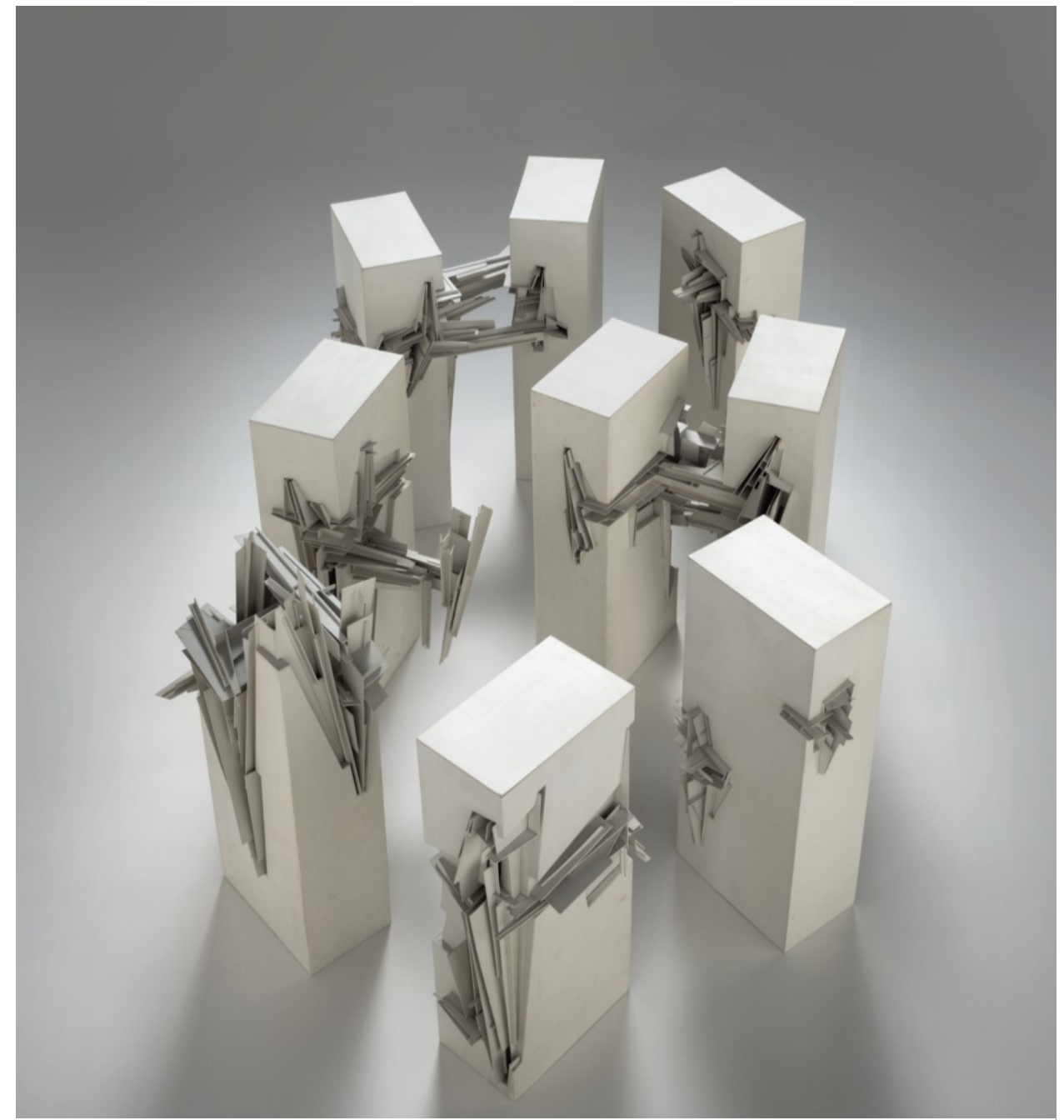

Figure 7: Lebbeus Woods, Nine Reconstructed Boxes, 1999; plastic models and ten sketches; 11 in. x $81 / 2$ in. (27.94 cm $x 21.59 \mathrm{~cm})$; Collection SFMOMA, Accessions Committee Fund purchase; (C) Estate of Lebbeus Woods; photo: Ben Blackwell 
"Architecture and Violence: Between Representation and Exchange” | Jenan Ghazal

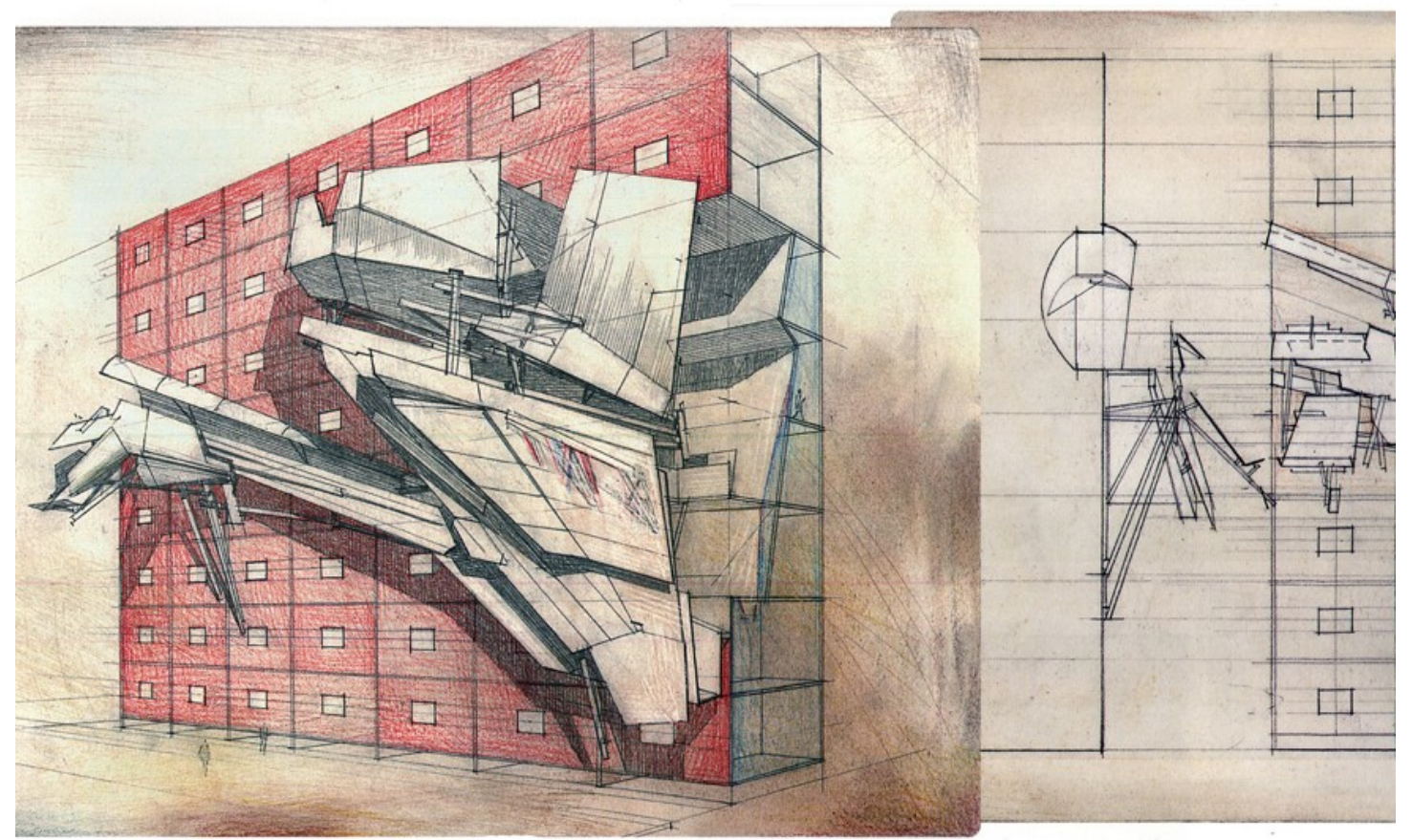

Figure 8 and 9: Lebbeus Woods. (Above and below) "A typical residential block, badly damaged in places, reconstructed with new types of spaces for residents' use. The principle here is that reconstruction integrates people's experiences of the destruction into needed social changes, as well as architectural ones. "Source: Lebbeus Woods's blog, https://lebbeuswoods.wordpress.com/2011/12/15/war.

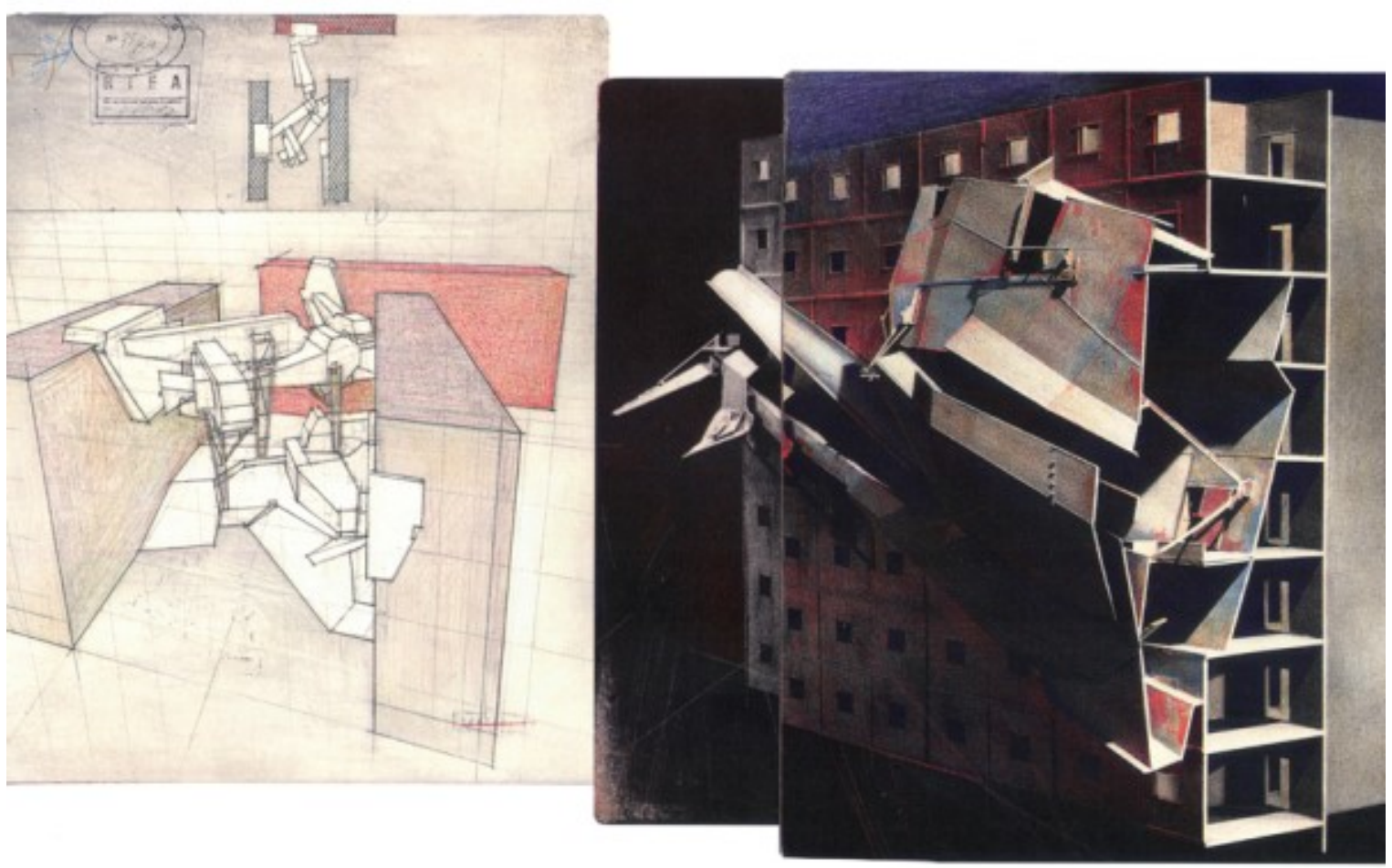




\section{Fourth space. Architecture and violence in the City: A personal tale.}

Destruction severely impacts architecture. In a war-torn city, damaged structures, destroyed buildings and ruins mark the scenes of violence; however, violence does not only affect the targeted structure, it has consequences for the relations between space and people associated with it. This chapter is a call to contemplate what changes and what remains the same following destruction in spaces of crisis. Thus, the argument here follows the "collision" between built and unbuilt environments and violence. It focuses on the moment of the first impact of violence on architecture, on the transformations that occur between built (tangible)/unbuilt (intangible), destroyed/undestroyed, and finally on the transitions that take place when violence challenges the nature of space.

The scars left on buildings are unique; each conceals stories of resilience. The citizens of the damaged city experience these spaces in crisis, according to Lebbeus Woods, they seek "eternal" existence through architecture. When their lives become radically altered following destruction, they should be able to see the change that they've been through. Architecture should be able to speak to the inhabitants of these buildings ${ }^{121}$ - their stories must be told. While observing, experiencing, analyzing, and reflecting on destruction, Lebbeus Woods initiated an experimentation relation between architecture and violence in places of crisis where he witnessed destruction. Here, I mimic his approach and project it onto my personal experience with destruction in Lebanon. In doing this, I intend to initiate another experiment through architecture and violence, not to echo Woods's voice, but rather to find my own.

${ }^{121}$ Woods, Radical Reconstruction, 16. 


\section{First Impact: The Turning Point}

While pointing at an immense skyscraper, a taxi driver in his mid-fifties, wandering his beloved city, tells stories of the civil war in Beirut twenty-five years ago. Although few ruins are still visible, and restorations were completed, he is not the only one living every day through his own memory of Beirut. While he drives through streets that once were war zones, it seems as if he does not merely see what is physically there, but he recalls what was once there, what happened and changed the fate of a city forever. At one point he says: "Here used to be a coffee shop just around the corner, where we would meet and discuss the latest news, a rocket came right through it and turned everything upside down. And nothing remains now." ${ }^{122}$ In his mind lives a city within a city, a hidden city, a lost city. There is an invisible pre-war Beirut and a visible post-war Beirut: the city before its encounter with violence and the city afterwards, the one that crossed to the other side along with whoever earned the title of "survivor."

In 2006, the Israeli army bombed the south suburbs of Beirut (the center of Hezbollah's activities.) ${ }^{123}$ The dense residential suburbs were almost completely destroyed - razed to the ground. In local TV coverage after the end of the 33-day war, an old man said: "I've never seen this area 'empty' like this since I was a young boy. When we first came it wasn't built yet. I see it now as if I was looking at it some fifty years ago, and now we have to build everything all over again!" 124 The total destruction did not allow any structure to remain above eye level, and inhabitants had a hard time remembering the location of their houses. Spaces converged and overlapped. This is not to suggest that destruction leads to the "un-existence" of architecture, though it creates this split through space, which acts as a window to the past.

\footnotetext{
122 Paraphrased conversation with a taxi driver in the summer of 2014 in downtown Beirut.

${ }^{123}$ Hezbolla is regarded as a Lebanese militia party, located mainly in the south of Lebanon.

${ }^{124}$ Paraphrased conversation of a report during the evening news broadcasted on a local Lebanese channel (Manar TV) in the summer of 2006.
} 
This "crossing" was performed both in time and through time, in space and through space. Destruction is the dismantling of what has been built, an act which turns a structure into ruins. It causes loss of material, but also a loss of time. While experiencing destruction, the city at the same time undergoes a process of time traveling, to the past. In Tripoli, as in Beirut, destruction was a turning point in the life of the city. The city's infrastructure and typology are being lost and downgraded through time. Eventually, it seems as if the city is reverting to the past in its very future. As it experiences this temporal split, this split is also visible in space.

For the taxi driver, and many others, there exists a shadow of a city that resides on the edge of forgetting; it does not belong entirely to the past, nor does it exist in the present. Rather, it remains solely in the collective consciousness of its inhabitants. Perhaps this "third city" could be partly made of collective memories and fragmented familiar scenes. It meshes the new space within the old one. Both what was destroyed and what was reconstructed coexist, somehow, between war and peace, complex layers of meaning exist and combine all these contradictions. Italo Calvino states that the city as collective memory, "does not tell its past, but contains it like the lines of a hand, written in the corners of the streets, the gratings of the windows, the banisters of the steps, the antennae of the lightning rods, the poles of the flags, every segment marked in turn with scratches, indentations, scrolls." ${ }^{25}$ In the "third city," perhaps it is possible to feel the presence of what is absent, or the absence of what was once present. In perceiving the presence of a new structure, one can be reminded of the absence of what occupied the same place before. And somehow, for a moment of time, the city becomes the place where that old coffee shop and that new skyscraper coincide, in a space that is not neutral but is tolerant.

${ }^{125}$ Italo Calvino, Invisible Cities, trans. William Weaver (New York: Random House, 2010), 11. 


\section{Scenes of destruction: The Transition}

A destroyed house is not a shelter anymore, a damaged school is not a place for education, and a fallen hospital does not offer medical care. Following violence and destruction, what kind of transitions might architecture undergo? The destruction of architecture in the city does not only affect the space that is physically bounded by its structure; rather, it brings consequences to other spaces, even if physically distant. Other spaces in the city now become new destinations for the former inhabitants of destroyed spaces. Their refuges will be the 'undestroyed' spaces. Hence, in times of war, citizens may develop opposing feelings towards the same space. They might feel safe because a roof shelters them from the violence outside those walls. And at the same time, the fear of the architecture collapsing on their heads in case of another attack resides in their mind. They explore new relations with different spaces that they have not experienced before. A city at war means a city desperately struggling for its survival. The quotidian lives of its citizens changes dramatically. They both abandon familiar spaces and are radically introduced to new ones. What are these spaces? How do spaces shift and transform? And what do they become?

During the armed conflict in Tripoli, twenty separate conflicts took place between 2008 and 2014, the conflict zones were in the middle of residential neighborhoods, and the most common kinds of weapons used were rifles, Kalashnikovs, and hand grenades. ${ }^{126}$ As a result, the majority of damaged buildings were still habitable, and their occupants made all kinds of basic repairs to broken windows and walls pierced by bullets. In spite of these attempts, some spaces were deserted because they were considered more dangerous than others. Some rooms were largely exposed to snipers because of windows' scale or position. In other spaces, wall thickness

\footnotetext{
126 Bazargan, "Neighbours at War."
} 
played an important role in shielding residents from bullets. Also, residents living in upper levels were forced to evacuate and seek other shelters.

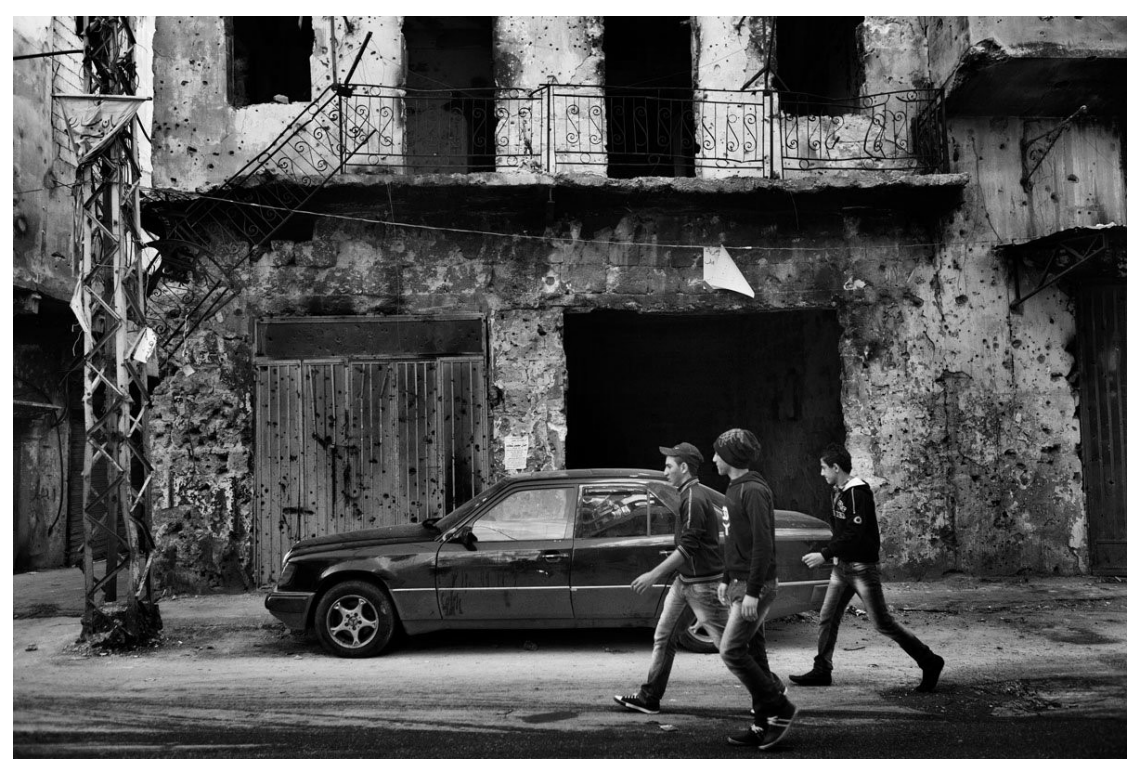

Figure 10: Laura Salvinelli. Tebenneh, stronghold of Sunni Muslims. Destruction and poverty are consequences of recurring fightings with Alawites of Jabal Mohsen or with the Libanese army. Tripoli, Lebanon, 2014. Source: Laura Salvinelli website.http://

These conditions pose fundamental questions about the flexibility of planning in uncertain situations: At times, architecture participates in the pain inflicted on the inhabitants, and at other times, it presents itself as a shelter from violence. It is important to note that what comes next is not limited to one specific city or place. Although each city is different, the ideas discussed here emerge from the destruction of architecture, which is common to all cities at war. This description emphasizes the transitions that take place in spaces of crisis-where the functions of the buildings, and the interactions and experiences of inhabitants change drastically due to violence. After recounting the tragic human conditions based on personal accounts of violence and destruction, the following discussion presents a taxonomy of spaces, both before and after the moment of destruction. 
It is important to explain that the nature of the discourse used here is distinct from previous sections. This is an 'experiment' in the discourse between architecture and violence that aims to 'freeze' different scenes of collision between violence and architecture and position it in a theoretical frame, drawing both on Andrew Herscher and Lebbeus Woods. As discussed above in chapter two with regards to Herscher's theory, registering and analyzing this collision serves to better understand destruction. This following succession of 'frames' is intended as a methodological device in explaining Herscher's 'warchitecture' theory which suggests that architecture is reconstituted every time it is destroyed. 'Warchitecture' is used as the base, and Woods's depiction and envisioning of architecture and violence - through his writings and drawings - is used to augment Herscher's position. His drawings capture a union between the damaged architecture (the victim) and the force of violence causing the damage (the weapon), creating a space that contains the old damage and the newly formed tissue. This complex structure embraces both destruction and construction in a space that is tolerant. ${ }^{127}$

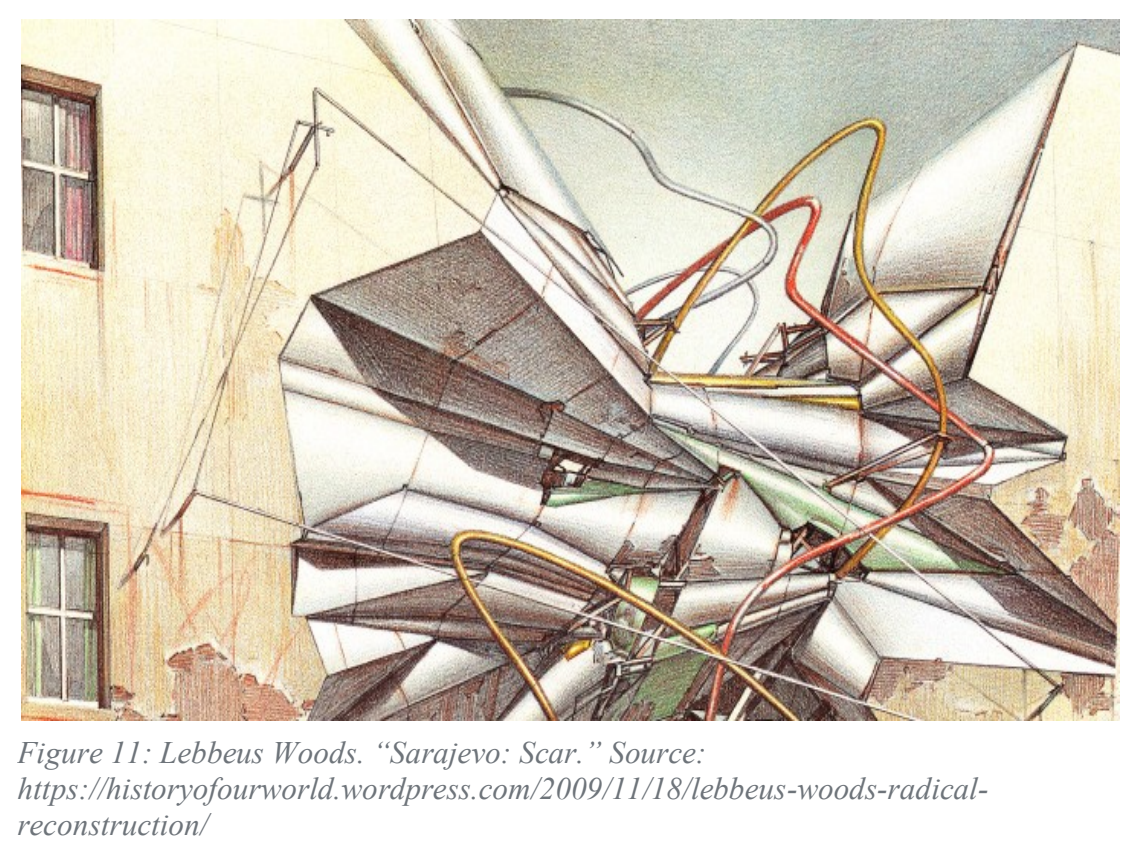

${ }^{127}$ Woods, Radical Reconstruction, 17. 
"Architecture and Violence: Between Representation and Exchange" | Jenan Ghazal

"Space is not one, but space is plural, space is a heterogeneity, a difference." 128

\section{Spiritual Spaces.}

Worshipers do not often come here. It is only in case of an event that crowds can be seen. Maybe a few come to confess, ask forgiveness for their sins, or ask for something they need. Normally, the voice of a prayer breaks the silence of space. However, in these times, supplications are heard every day and almost continuously. Now, the "new" believers are seen in every corner, lighting candles or showing humility with their hands up to the sky and their face down to the earth. They do not come here just to pray. Non-believers, people from different faiths, find refuge in these buildings. The concept of immunity — according to which people and places should be spared, respected and protected from violence — grant these structures a space of assured refuge for anyone. However, the perpetrators of violence often do not play by the rules of engagement. Religious places are in some situations primary targets. The act of burning a church or destroying a mosque is a recurrent headline in wars based on ethnicity or religious conflict. This violence tends to be reciprocal, meaning the violence on one building (the victims') triggers sentiments of anger and vengeance, thus "justifying" an attack on the perpetrators. Violence becomes mimetic. ${ }^{129}$

\section{High Spaces.}

The height of a structure is an important matter, and it often poses challenges both to architects and inhabitants. Moreover, high structures are often landmarks within the city. The difference in heights among these landmarks shapes the skyline silhouette of the city. The higher the structure

\footnotetext{
${ }^{128}$ Daniel Libeskind, “The End of Space," Transition 44/45 (1992): 86-91.

${ }^{129}$ Herscher, Violence Taking Place, 126.
} 
is, the more landscape is revealed. From up there, the city consists of an ideal scene, with its visible lines, strong geometry, and different shapes. However, they are vacant spaces now, because they stand out in the city and thus are easily targeted. Due to their scale in comparison to everything around them, their destruction has an enormous impact on the surrounding and entails chaotic devastation. Essentially, to their destroyers, that is the vital "advantage" of targeting such landmarks. Their provoking design and strong visible presence contribute simultaneously to their weakness in front of violence. In times of chaos, no one wants to be seen; many are solely concerned with remaining alive, often hiding under the radar, which is contradictory to a tower's function.

These spaces are also often apprehended by invaders, serving to efficiently control the city and track any movement. The new inhabitants are now snipers. From up high, they can target anything and anyone. They turn streets into deadly shooting galleries. And thus the buildings around them turn into death traps.

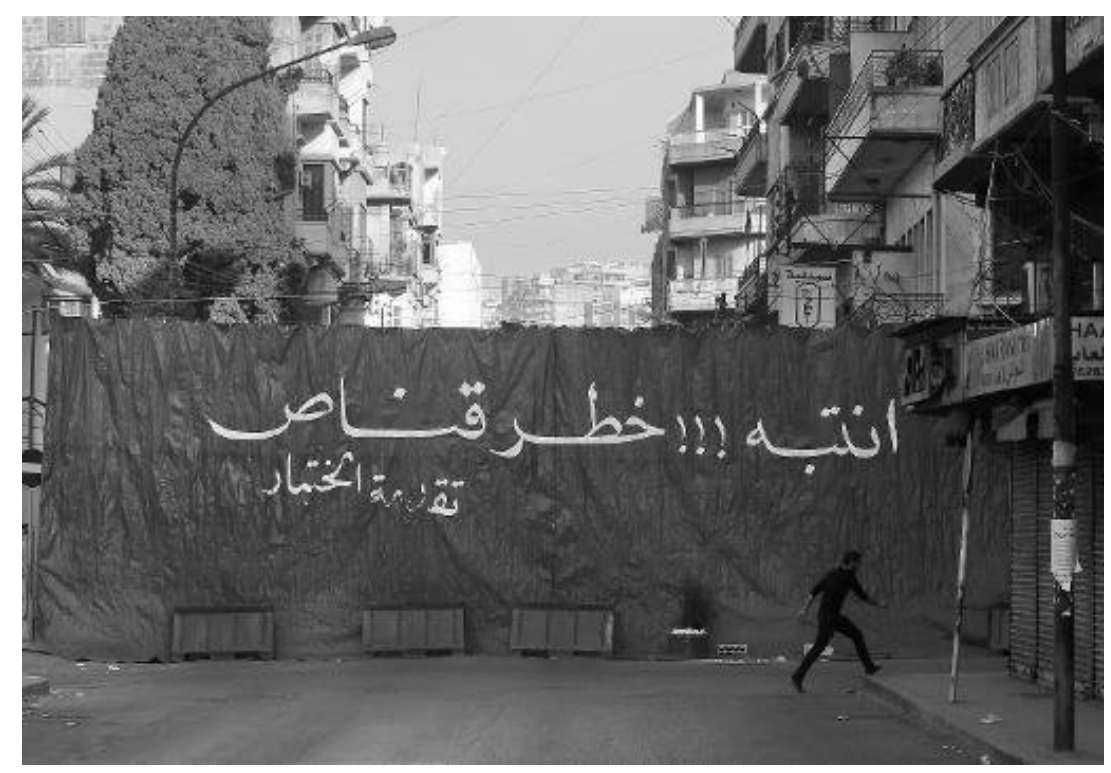

Figure 12: 'Be aware!!! Danger of snipers' - A large curtain wall clocking the road to warn pedestrians to not cross to the other side. Tripoli-Lebanon. Source: Naharnet news deck 18 January 2014 http://www.naharnet.com/stories/en/114556 
In these spaces of violence, walls become traps for inhabitants. This siege mentality is empowered by fear of the outside where violence is taking place. This suggests how architecture can become a "median" platform for the exchange of violence between two opposing sides, and also a medium of violence against its own inhabitants. The destruction of architecture is a demonstration of the perpetrators' power, as well as the victims' powerlessness. However, notions of inside violence and outside violence assert another one: Architecture can be also an apparatus of violence against itself. Or perhaps, architecture encloses violence within itself. War, fear, and destruction act as stimuli for violence to unveil itself within the city. ${ }^{130}$ However important this notion may be, it is incomplete. It undermines the position of architecture in front of violence and suggests that it is merely complicit in its own destruction.

Expanding on this, following the 2001 attack on the World Trade Center and the shocking destruction of iconic architecture, footage of the collapse of the towers and images of the overwhelming destruction were replayed time and again, even obsessively, for several months. ${ }^{131}$ The moments of the collision of the airplanes with the towers and the moments of collapse were the most common scenes on TV. ${ }^{132}$ The perpetrators of this violence carefully chose their target: An architecture that is strongly visible, known and recognizable worldwide, an object of both criticism and admiration, and an architecture that is celebrated as a landmark, one whose destruction create another disastrous destruction that expand beyond the area in crisis.$^{133}$ Once the attack took place, the media staged a monstrous spectacle out of the destroyed

\footnotetext{
${ }^{130}$ Although common to all cities, this process is not the same everywhere. Its level of manifestation depends primarily on the nature and role of architecture in the city, and the transition it went through due to destruction and violence.

${ }^{131}$ Brigitte Lebens Nacos, Mass-Mediated Terrorism: The Central Role of the Media in Terrorism and Counterterrorism (Lanham, MD: Rowman \& Littlefield, 2007), 223.

${ }^{132}$ Ibid.

${ }^{133}$ Ibid, 41.
} 
buildings, even a theatrical production. ${ }^{134}$ This played into the intention of the perpetrators, affecting their "audience in unprecedented and lasting ways." 135 This theatrical play of violence used architecture itself in its own execution. This "play" might even appear as a continuation or an extension of violence on architecture, thus making violence even more visible and expressive.

In regard to this, Herscher notes "architecture should be understood to advance and legitimate violence as much as to resist, or disregard it." ${ }^{" 136}$ Lebbeus Woods seems to agree with Herscher, referring to his book Radical reconstruction, he states that when violence attacks architecture, it becomes clear how architecture can be part of the problem; it is observable how it is used in the killing of innocent men, women and children. However, Woods continues to stress that as long as he was witnessing these scenes of destruction, it became clear to him that architecture is indeed part of the solution. ${ }^{137}$ In interpreting these views from both Herscher and Woods let us continue dwelling on other types of spaces where architecture can resist violence in Herscher's words - and offer a solution to the inhabitants - in Woods's words - by becoming a shelter from destruction.

\section{Underground Spaces.}

The dynamic type of space largely serves circulation purposes. The space that cuts harshly through the city's veins without permission. Sometimes, it exists silently under crowded surfaces, other times it becomes a storm beneath calm and quiet environments. Its users are always in a hurry; for them, this place is never their last destination, but rather represents a

\footnotetext{
134 Ibid, 45.

135 Ibid.

${ }^{136}$ Herscher, "warchitectural theory," 35-43.

137 "WAR AND ARCHITECTURE: The Sarajevo window,” an entry on LEBBEUS WOODS. Published: December 2, 2011. Accessed via https://lebbeuswoods.wordpress.com/2011/12/02/war-and-architecture-the-sarajevowindow/?blogsub=confirming\#subscribe-blog
} 
passage to other spaces. They expect nothing less than speed, accuracy, and convenience.

Although crowded at rush hours, no one is interested in socializing with the person sitting beside them. The same routine takes place daily: a group of strangers gathers in a closed tube-shaped space and crosses to the other side of town at the same time. Until now, these spaces were the ultimate hiding place from the violence of war, as everywhere above ground became a perilous space. Describing the London Underground system, Annette Fiero notes:

At the height of the bombings, the depth of the London Underground made it the perfect shelter; the beloved "Tube" was taken over for housing as well as light industry. Offering refuge for as many as 177,000 Londoners at night, many of the new and disused extensions of the subway tunnels were eventually retrofitted with standardized systems of partitions, bed-frames and other domestic fitting, as well as machinery for war-time industrial production. [...] The underground was a life-line for the city of many descriptions and dimensions. ${ }^{138}$

What was once a purely dynamic space experienced a radical transformation into a temporary fixed location, where people sat together with their luggage, albeit this time going nowhere.

These underground places were now their only destination. Although they did not see the horrors on the surface, they sometimes heard the sound of it above their heads.

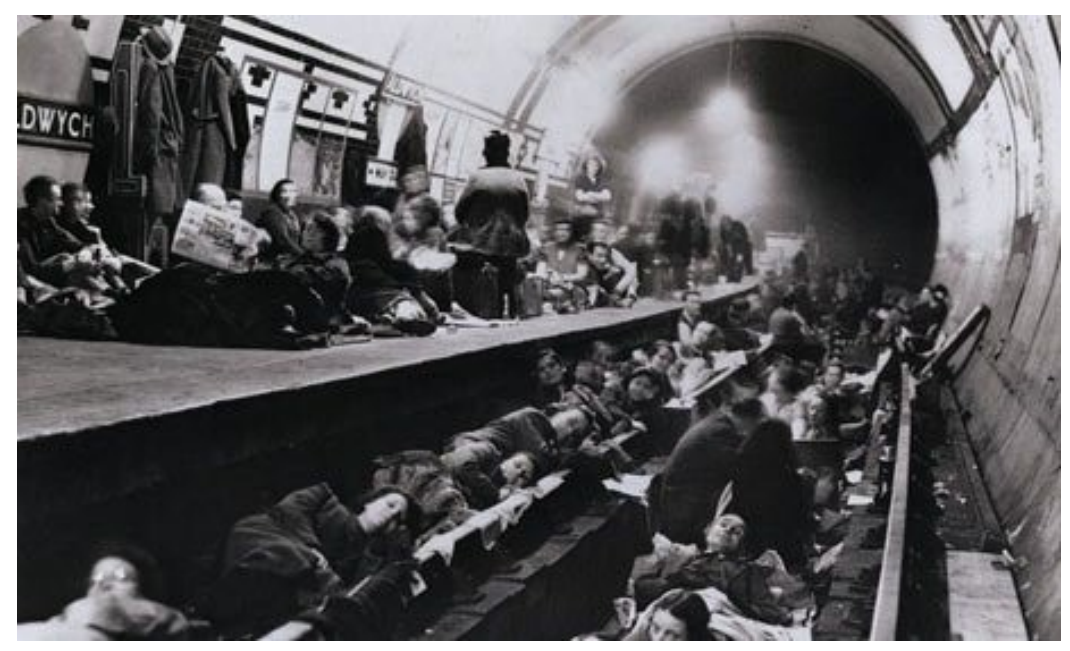

Figure 13: Photograph: Bettmann/Corbis. Londoners shelter in a tube station during the Second World War. Source: The Guardian,

http://www.theguardian.com/world/2009/sep/06/blitz-second-world-war

${ }^{138}$ Annette Fierro, Inscription of Violence: London's Landscape of Commemoration (ACTAR, 2011$), 61$. 


\section{Vast spaces.}

Spaces that can accommodate hundreds or even thousands of citizens. These structures designed outside human proportions, to the scale of a city or a country, are now filled to their maximum capacity. These places were not originally intended to gather people on a daily basis. They were designed with a sense of luxury. Previously, their capacity appeared exaggerated or unrealistic to some visitors. Although, on certain events, someone from the crowd can be heard shouting "there is no more space." Despite how diverse these events are, violence, without a doubt, do gather the sheer numbers of spectators. This time, they are not visitors; they simply do not have anywhere else to go.

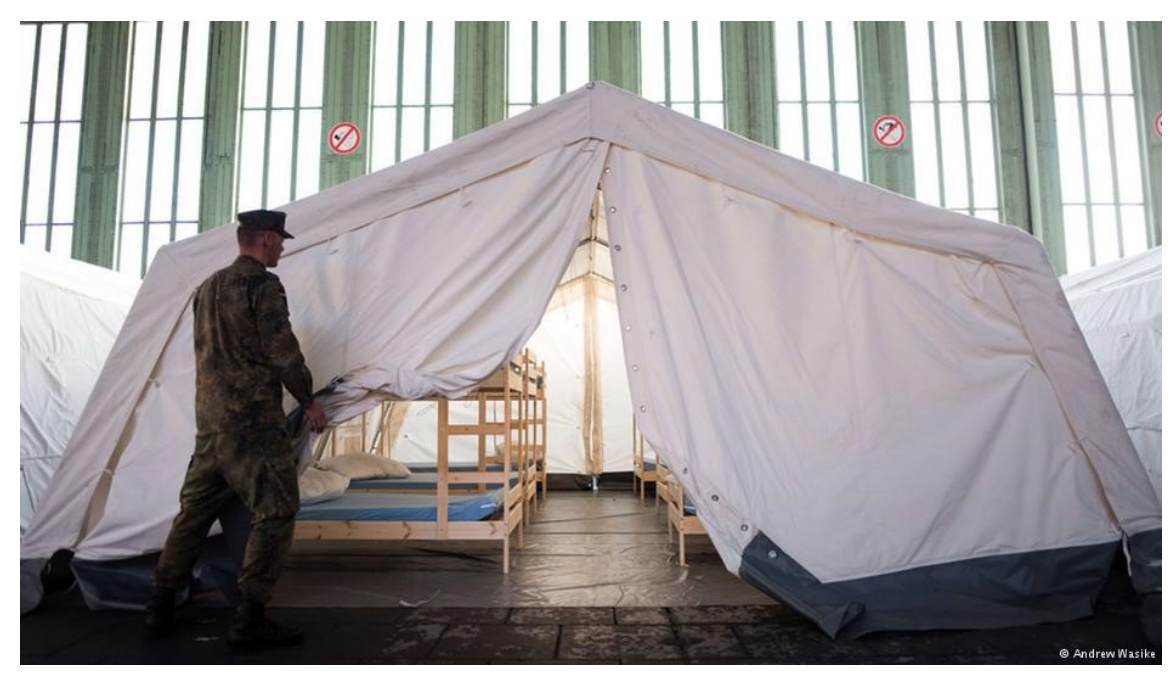

Figure 14: Andrew Wasike. "Some 2,500 refugees are currently housed at Tempelhof airport." Source: DW website. http://dw.com/p/1HG2R

Today, civil war and violence bursting in countries in the Middle East and Africa forced people to search for a safer place to live. ${ }^{139}$ Europe is witnessing one of the most significant refugee crisis in its history. ${ }^{140}$ In Berlin, "the city is already housing refugees in old aircraft

\footnotetext{
${ }^{139}$ Why is EU struggling with migrants and asylum? BBC news. Published 3 March 2016, accessed on April 8, 2016 via http://www.bbc.com/news/world-europe-24583286

${ }^{140}$ Ibid.
} 
hangars, disused department stores, and even the former Stasi headquarters, but one ongoing battleground remains the city's indoor sports facilities, of which 36 have been requisitioned and repurposed as emergency shelters." ${ }^{141}$ The city is struggling to find places to shelter hundreds of refugees arriving every day. ${ }^{142}$ The mayor of Berlin's central district of Mitte, "where three sports halls are now refugees' shelters, said large venues like the Velodrom and the Ostbahnhof Arena would make better shelters." 143

\section{Spaces for the "Dead."}

For everyone, cemeteries are the place where their journey ends. Not often visited, these spaces may exist on the edge of or outside cities. They are places where architecture humbles itself to the humans who will inhabit the earth underneath: A pile of stones with small engravings honor the memory and hide whatever stories left untold. They do not invite much celebration and are hardly subject to change. They have always been constructed in this general form and most likely will continue to be. When war hits, these spaces become more familiar, and come back to life for those seeking shelter or a place to sleep, away from the city and its violence.

\footnotetext{
${ }^{141}$ Ben Knight, "Berlin's tug-of-war over space to house refugees.” DW news. Berlin, published 03.12.2015 accessed on April 8, 2016 via http://www.dw.com/en/berlins-tug-of-war-over-space-to-house-refugees/a-18889567 142 Ibid.

143 Ibid.
} 


\section{Conclusion. Violence and Architecture: Towards new beginnings}

"There was a silly damn bird called a phoenix back before Christ, every few hundred years he built a pyre and burnt himself up. He must have been the first cousin to Man. But every time he burnt himself up he sprang out of the ashes, he got himself born all over again. And it looks like we're doing the same thing, over and over, but we've got one damn thing the phoenix never had. We know the damn silly thing we just did. We know all the damn silly things we've done for a thousand years, and as long as we know that and always have it around where we can see it, someday we'll stop making the goddamn funeral pyres and jumping in the middle of them." "144 -Ray Bradbury

Aldo Rossi understood that the city embodies the collective memory of society, and that the city links places and people. ${ }^{145}$ Architecture thus becomes the shared platform that allows all sorts of human activities, giving them space to thrive. Human experiences thus conceived constitute the soul of the city. Architecture is the city; the city is architecture. Throughout time, invaders, destroyers, and perpetrators of violence have made the destruction of certain types of architecture their main focus. To legitimize their actions, they frame destruction as collateral damage, or a military necessity, or as the elimination of incubators for "hostile" activities. Once architecture is equated with the functions it serves, or the representations it reflects, it ceases to exist as architecture; rather it becomes a target — a mark on a map, a green cross on a digital screen, or a pixelated satellite image used in a press conference. These methods aim to "defamiliarize" architecture and reduce its meaning, in preparation for its destruction.

Upon its destruction, architecture becomes immediately reduced in meaning and representation. As discussed above, in the midst of war certain buildings are prone to attack more

\footnotetext{
144 Ray Bradbury, fahrenheit 451. Simon and Schuster, (1967), 163.

${ }^{145}$ Rossi and Eisenman, The Architecture of the City.
} 
than others - this could be due to a particular function, a strategic location in the city, or because of who uses the facility. Those structures are indeed the first to be abandoned, and also those most likely to be avoided. For instance, architecture that influences power and represents the body of a state (or one of the parties at war) is already participating, either directly or indirectly, in the scene of violence.

Herscher argues that violence is a form of inscription akin to other cultural forms, and considers it as "an investment of material with identity and meaning." ${ }^{146}$ It is irreducible to the intention of a "destroyer" or to a context. However, for architecture, it is the design process that is solely regarded as an inscription of meaning, and is often celebrated as such. Destruction thus converts architecture from inscription to transcription, in other words, from the creation of identity and meaning to its circulation—essentially a deviation of architecture's own founding notion. ${ }^{147}$ The focus shifts from architecture as an object that invites critical interpretation to an object that expresses a superficial context: what is destroyed? When was it destroyed and who destroyed it? Destruction brought upon architecture, this violence against 'a sign or a symbol,' is intended to render the target invisible, dismantled, or deformed, disfigured and ugly, and thus unworthy of admiration or even existence.

However, destruction inflicted on a building does not always embody uselessness, and eventually death; on the contrary, it can allow for its transformation into a more powerful urban artifact that acquires an "intensified visibility" and a stronger identity. ${ }^{148}$

The theory of 'warchitecture' proposed by Hersher and explained here, expands the conception of architecture beyond the limited understanding of architecture in terms of

\footnotetext{
146 Ibid., 4

147 Ibid.

148 Ibid, 88.
} 
construction. Through 'warchitecture,' Herscher argues that destruction is not considered outside the domain of architecture, so ultimately it cannot be reduced "to its contexts, nor to the intentions of its authors, nor to its effects on its targets." ${ }^{" 149}$ Destruction can both consist of "a targeting of culture and a cultural form in itself." ${ }^{\prime 150}$ It should be regarded as a transformation rather than an eradication of architecture from space - a transformation of status, meaning, and culture. Indeed, these transformations should never be regarded merely as the remains of destroyed spaces; rather, as Herscher suggests, these degraded layers of destruction should be “enmeshed" with the old ones. ${ }^{151}$

Architectural violence does not consist only of the things that befall architecture, but rather, of this collision between the built environment and the political, social, religious connections to everything around it. In spaces of crisis, a dynamic state prevails that disrupts the balance of the old order, along with its walls and borderlines. In explaining this, Lebbeus Woods affirms: "architecture must learn to transform violence, even as violence knows how to transform architecture." ${ }^{152}$ It should not fear its collision with violence. The scars that result from such encounters are evidence of an ugly violence, but also of powerful experiences of resilience. 'Freedom Graffiti ${ }^{153}$ dramatically embodies the union between architecture and violence. It asserts Herscher's notion of violence as an inscription of meaning, but also it equally demonstrates the possibility of art's and architecture's voice to be louder than the sound of violence and destruction.

\footnotetext{
${ }^{149}$ Herscher, "warchitectural theory," 35-43.

150 Ibid.

${ }^{151}$ Herscher, Violence Taking Place, 9.

152 Woods, Radical Reconstruction, 16.

${ }^{153}$ See Figure 1: A kiss for the whole world: Tammam Azzam's version of Klimt's "The Kiss."
} 
After all, architecture should aim to address the "human condition" through all its variable expressions. It must not only celebrate "fashionable" new building designs and the masterminds behind them (who belong to the "new" world of power and economics), but also emphasize the important transformations that take place in spaces that have experienced struggles for existence, ${ }^{154}$ where violent forces have brutally damaged architecture.

In these spaces, beginnings ought to happen, not endings.

\footnotetext{
${ }^{154}$ Woods, The Storm and the Fall, 20.
} 


\section{Bibliography}

\section{Books}

Arendt, Hannah. Eichmann in Jerusalem: A Report on the Banality of Evil. London: Penguin, 1976.

Arendt, Hannah. On Violence. New York: Houghton Mifflin Harcourt, 1970.

Becker, Joseph, and Jennifer Dunlop Fletcher. Lebbeus Woods, Architect. Drawing papers, vol. 114, New York: The Drawing Center, 2014.

Bevan, Robert. The Destruction of Memory: Architecture at War. London: Reaktion Books, 2007.

Calvino, Italo. Invisible Cities. Trans. William Weaver. New York: Random House, 2010.

Clausewitz, Carl von. On War. Ed. and trans. Michael Howard and Peter Paret. 1976.

Ellul, Jacques, and Robert King Merton. The Technological Society. New York: Vintage Books, 1964.

Herscher, Andrew. Violence Taking Place: The Architecture of the Kosovo Conflict. Stanford: Stanford University Press, 2010.

Kahn, Louis I., and Dung Ngo. Louis Kahn: Conversations with Students. No. 26. Princeton Architectural Press, 1998.

Kenzari, Bechir. Architecture and Violence. ACTAR Publishers, 2011.

Milgram, Stanley. Obedience to Authority: An Experimental View. New York: Harper \& Row, 1974.

Rossi, Aldo, and Peter Eisenman. The Architecture of the City. Cambridge, MA: MIT Press, 1982. 
Woods, Lebbeus. Pamphlet Architecture 15: War and Architecture. New York: Princeton Architectural Press, 1993.

Woods, Lebbeus, Aleksandra Wagner, and Michael Menser. Radical Reconstruction. New York: Princeton Architectural Press, 1997.

Woods, Lebbeus. OneFiveFour. New York: Princeton Architectural Press, 1989.

Woods, Lebbeus. The Storm and the Fall. New York: Princeton Architectural Press, 2004.

\section{Web Accessed}

Bakarsic, Kemal. "The Libraries of Sarajevo and the Book that Saved our Lives." The New Combat: A Journal of Reason and Resistance, (1994): 13-15. Accessed December 2016, http://www.newcombat.net/article_thelibraries.html.

Bazargan, Darius. “Neighbours at War in Lebanon's Divided City of Tripoli.” BBC News, Tripoli, Lebanon. 6 February 2013. Accessed March 20, 2016, http://www.bbc.com/news/world-middle-east-21336372.

Blass, Thomas. “The Milgram Paradigm after 35 Years: Some Things We now Know about Obedience to Authority.” Journal of Applied Social Psychology 29, no. 5 (1999): 955-978. Accessed November 2015, http://www2.psych.ubc.ca/ schaller/Psyc591Readings/Blass1999.pdf.

Burger, Jerry M. “Replicating Milgram: Would People Still Obey Today?” American Psychologist 64, no. 1 (2009): 9. Accessed November 2015, https://www.apa.org/pubs/journals/releases/amp-64-1-1.pdf.

Herscher, Andrew. "Warchitectural theory." Journal of Architectural Education 61, no. 3 (2008): $35-43$.

Jones, Jonathan. "Tammam Azzam's Kiss: an unromantic commentary on the Syrian conflict." 
The Guardian, Monday 4 February 2013 16.51 GMT Accessed on 28/1/2016, via http://www.theguardian.com/artanddesign/jonathanjonesblog/2013/feb/04/syria-klimtkiss-tammam-azzam.

Knell, Yolande. "Lebanese City of Tripoli Rocked by Deadly Explosions.” BBC News, Beirut, 23 August 2013. Accessed on 9 January 2016, http://www.bbc.com/news/world-middleeast-23811328.

Milgram, Stanley. "Behavioral Study of Obedience." The Journal of Abnormal and Social Psychology 67, no. 4 (1963): 371-378. Accessed March 2016, http://isites.harvard.edu/fs/docs/icb.topic606668.files/Course\%20Readings/94\%20The\%2 0Moral\%20Self/milgram.obedience.1963.pdf.

Woods, Lebbeus. The Sarajevo Window. Accessed 18 March 2016, https://lebbeuswoods.wordpress.com/2011/12/02/war-and-architecture-the-sarajevowindow. 